\title{
Genetic data of museum specimens allow for inferring evolutionary history of the cosmopolitan genus Sirthenea (Heteroptera: Reduviidae)
}

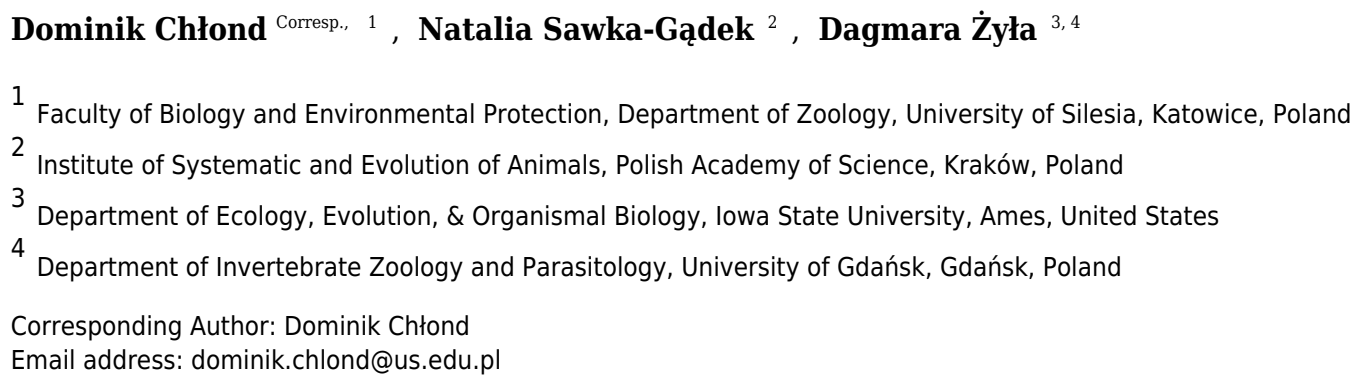

Among the 30 known genera within subfamily Peiratinae, only the genus Sirthenea has a cosmopolitan distribution. The results of our studies are the first comprehensive analysis concerning one of the representatives of mentioned subfamily based on joint phylogenetic analyses of molecular and morphological data as well as molecular dating. A total of 32 species were included into the dataset with all known species of the genus Sirthenea . Material of over 400 dry specimens was examined for the morphological part of this study. The cosmopolitan distribution of Sirthenea and the inaccessibility of specimens preserved in alcohol required the extraction of DNA from the dried skeletal muscles of specimens deposited in 24 entomological collections. The oldest specimens used for the successful extraction and sequencing were collected more than 120 years ago in India. We performed Bayesian Inference analyses of molecular and morphological data separately, as well as combined analysis. The molecular and morphological data obtained during our research verify the correlation of the divergence dates of all known Sirthenea species. Results of the relaxed molecular clock analysis of the molecular data show that, the genus Sirthenea started diverging in the Late Cretaceous into two clades, which subsequently began to branch off in the Paleocene. Our results of phylogenetic analyses suggest that the fossula spongiosa and its development could be one of the most important morphological characters in the evolution of the genus, most likely associated with the ecological niche inhabited by Sirthenea representatives. Confirmation of the results obtained in our studies is the reconciliation of the evolutionary history of Sirthenea with the biogeographical processes that have shaped current global distribution of the genus. 
1 Genetic data of museum specimens allow for inferring evolutionary history of the cosmopolitan

2 genus Sirthenea (Heteroptera: Reduviidae).

3

4 Dominik Chłond ${ }^{1}$, Natalia Sawka-Gądek², Dagmara Żyła ${ }^{3,4}$

5

$6{ }^{1}$ Department of Zoology, Faculty of Biology and Environmental Protection, University of

7 Silesia, Katowice, Poland

$8{ }^{2}$ Institute of Systematic and Evolution of Animals Polish Academy of Science, Kraków, Poland

$9{ }^{3}$ Iowa State University, Department of Ecology, Evolution, \& Organismal Biology, Ames,

10 United States of America

$11{ }^{4}$ University of Gdańsk, Department of Invertebrate Zoology and Parasitology, Gdańsk, Poland

Dominik Chłond ${ }^{1}$

Email address: dominik.chlond@us.edu.pl 


\section{Abstract}

27 Among the 30 known genera within subfamily Peiratinae, only the genus Sirthenea has a cosmopolitan distribution. The results of our studies are the first comprehensive analysis concerning one of the representatives of mentioned subfamily based on joint phylogenetic analyses of molecular and morphological data as well as molecular dating. A total of 32 species were included into the dataset with all known species of the genus Sirthenea. Material of over 400 dry specimens was examined for the morphological part of this study. The cosmopolitan distribution of Sirthenea and the inaccessibility of specimens preserved in alcohol required the extraction of DNA from the dried skeletal muscles of specimens deposited in 24 entomological collections. The oldest specimens used for the successful extraction and sequencing were collected more than 120 years ago in India. We performed Bayesian Inference analyses of molecular and morphological data separately, as well as combined analysis. The molecular and morphological data obtained during our research verify the correlation of the divergence dates of all known Sirthenea species. Results of the relaxed molecular clock analysis of the molecular data show that, the genus Sirthenea started diverging in the Late Cretaceous into two clades, which subsequently began to branch off in the Paleocene. Our results of phylogenetic analyses suggest that the fossula spongiosa and its development could be one of the most important morphological characters in the evolution of the genus, most likely associated with the ecological niche inhabited by Sirthenea representatives. Confirmation of the results obtained in our studies is the reconciliation of the evolutionary history of Sirthenea with the biogeographical processes that have shaped current global distribution of the genus. 


\section{Introduction}

57

58

Reduviidae, also known as assassin bugs, with ca. 6800 described species, are one of the largest and most morphologically diverse families of Heteroptera, currently subdivided into 25 subfamilies (Zhang et al., 2015; Weirauch et al., 2014). Among these, the subfamily Peiratinae is known from 30 described genera (Putshkov \& Putshkov 1986-1989; Maldonado, 1990; Coscarón, 1995, 1996, 1997, 2002; Coscarón \& Linnavuori, 2007; Coscarón \& Morrone, 1995; Gil-Santana \& Costa, 2003; Cai \& Taylor, 2006). The distribution of Peiratinae has been the subject of many studies (Morrone \& Coscarón, 1996, 1998; Coscarón, 2017, Coscarón \& Carpintero, 1994; Coscarón \& Morrone, 1995, 1997; Coscarón 1983a, b, 1984, 1986, 1994, 1996, 1997, 2002), and it has recently been comprehensively revised (Chłond \& BugajNawrocka, 2015). In addition, the above-mentioned studies show that we can clearly distinguish groups of genera with a distribution limited to specific zoogeographical regions. Among all of the known Peiratinae, only the genus Sirthenea Spinola, 1837 has a cosmopolitan distribution, which is not a frequent phenomenon within Reduviidae (Maldonado, 1990). Therefore, Sirthenea is of considerable interest as a potential model group for a wide range of studies spanning several fields such as evolutionary biology, systematics, biogeography and ecology. Our previous study showed that representatives of Sirthenea are ground-dwelling, non-specialised predators that prey on other insects on the ground in microhabitats that are mainly located in low-lying areas in tropical and temperate climates (Chłond \& Bugaj-Nawrocka, 2015), which is consistent with the observations of other authors (e.g. Willemse, 1985). During the almost two centuries since the description of the first Sirthenea species as Reduvius carinatus by Spinola in 1837, the number of known species has increased to 41 (Maldonado, 1990; Cai \& Tomokuni 2004; Chłond 2008a, b), which was largely due to the high degree of variability associated with the wide distribution of selected species. The combination of the above-mentioned factors, as well as the existence of geographical barriers, in some cases enable allopatric speciation (Chłond et al., 2017). In turn, this has resulted in a large number of described species, which are often only synonymous with geographical forms that are characterised by a high degree of polychromatism (Chłond, 2018). However, at the end of the twentieth century, the number of known species of Sirthenea changed 
85

86

87

as the New World representatives were revised (Willemse, 1985), which increased the number of known Neotropical species from nine to 13. Conversely, the revision of the Old World species (Chłond, 2018) reduced the number of known species from the Afrotropical, Oriental, Palearctic and Australian zoogeographical regions by half from 28 to 14 species (including descriptions of two new species). Even though the taxonomy of the genus Sirthenea is rather well understood, no attempt has been made to study the phylogenetic relationships within the genus.

For many insect groups, the standard collecting of high-quality DNA material only began a few years ago, and therefore, DNA-grade samples for many taxa that are critical for various phylogenetic analyses are still not available. Due to the inaccessibility of specimens that had been preserved in alcohol, we used the dried skeletal muscles of specimens that belong to all of the known species of Sirthenea deposited in 24 entomological collections to obtain the molecular data for our analysis. The oldest individuals that were used for the successful extraction and sequencing belong to a newly described species, $S$. kali Chłond, 2018, which was collected as long ago as in 1898 in Northeast India (West Bengal). The usefulness of our method and the possibility of obtaining DNA from museum specimens of various ages that had been stored in different museum conditions were previously reported in Chłond et al. (2017) and are further confirmed here.

Our results provide a hypothesis for understanding the evolutionary history of the genus, which is supported by the evolution of the ecological niches that are occupied by representatives of Sirthenea (Couvreur \& Baker, 2013; Chłond \& Bugaj-Nawrocka, 2015). Moreover, all of the information that was obtained during previous studies (Chłond \& Bugaj-Nawrocka, 2015; Chłond et al., 2017; Chłond, 2018) combined with the currently obtained data, which can be linked to geological time, not only provide valuable insight into the evolutionary history of the Sirthenea, but also allow for understanding the diversity (27 species) of this cosmopolitan genus. In this study, we aimed to investigate the phylogenetic relationships of Sirthenea based on morphological and molecular data, and to estimate the divergence times within all of the known species of Sirthenea.

\section{Material \& Methods}

\section{Molecular data:}


115

116

117

118

119

120

121

122

123

124

125

126

127

128

129

130

131

132

133

134

135

136

137

138

139

140

141

142

143

144

145

\section{Taxon sampling}

The ingroup sample consisted of 27 individuals representing the genus Sirthenea. Five species were selected as the outgroup taxa for the analysis. The collection data of the specimens and their GenBank accession numbers are provided in TableS1.

\section{DNA extraction, amplification and sequencing}

DNA was extracted from the dried skeletal muscles of each specimen. Genomic DNA was isolated without modifying the protocol using the GeneMATRIX Bio-Trace kit (EURx, Gdańsk, Poland). To elute the purified DNA, we applied $50 \mu \mathrm{L}$ of an Elution Buffer onto the silica membrane. To amplify a fragment of the mitochondrial cytochrome c oxidase I (COI) gene, the primer pair C1J2186 (Simon et al., 1994) and C1N2608 (Damgaard et al., 2000) was used.

In some cases, when the above COI pair of primers did not yield a well-defined product, overlapping internal primers were used (COI-ScF2 5' - TTTTGATTTTTTGACATCCTGA - 3', COI-ScR1 5'- TCCTACTGTAAATATATGGTG -3'). To amplify a fragment of the $18 \mathrm{~S}$ ribosomal gene, the primer pair 18S-ScF1 5'-CCTGTCGGTGTAACTGGCAT-3', 18S-ScR 5'GCTGGCTGGCATCGTTTATG-3' was used.

Polymerase chain reaction (PCR) amplification for all DNA fragments that were analysed was carried out in a final volume of $20 \mu \mathrm{L}$ containing $30 \mathrm{ng}$ of DNA, $1.25 \mathrm{U}$ Perpetual OptiTaq (EURx, Poland), $0.4 \mu \mathrm{L}$ of $20 \mu \mathrm{M}$ of each primer, $2 \mu \mathrm{L}$ of 10x Pol Buffer B and $0.8 \mu \mathrm{L}$ of $5 \mathrm{mM}$ dNTPs in a Mastercycler ep system (Eppendorf, Hamburg, Germany). The cycling profile for the PCR was: $95^{\circ} \mathrm{C}$ for $2 \mathrm{~min}, 35$ cycles of $95^{\circ} \mathrm{C}$ for $30 \mathrm{sec}, 45^{\circ} \mathrm{C}$ for $30 \mathrm{sec}, 72^{\circ} \mathrm{C}$ for $1 \mathrm{~min}$ and a final extension period of $72^{\circ} \mathrm{C}$ for $7 \mathrm{~min}$.

In order to assess the quality of the amplification, the PCR products were electrophoresed in $1 \%$ agarose gel for $45 \mathrm{~min}$ at $85 \mathrm{~V}$ with a DNA molecular weight marker (Mass Ruler Low Range DNA Ladder, Thermo-Scientific, Waltham, MA, USA). The PCR products were purified using Exo-BAP (EURx, Poland).

Samples were sequenced in both directions using the same primers as for the PCR reactions combined with a BigDye Terminator 3.1 Cycle Sequencing Kit (Applied Biosystems, (ABI) Foster City, CA, USA) using the chain termination reaction method (Sanger et al., 1977). The sequencing reaction was carried out with the PCR product at a total volume of $20 \mu \mathrm{L}$ containing 
$1462 \mu \mathrm{L}$ of BigDye Terminator Reaction Ready Mix v. 3.1 (ABI), $2 \mu \mathrm{L} 5 \times$ sequencing buffer (ABI),

$1473.2 \mathrm{~mol} / \mu \mathrm{L}$ of the primer solution and $6 \mu \mathrm{L}$ of the purified PCR product. The cycle-sequencing

148 profile was $3 \mathrm{~min}$ at $94^{\circ} \mathrm{C}$ followed by 30 cycles of $10 \mathrm{~s}$ at $96^{\circ} \mathrm{C}, 5 \mathrm{~s}$ at $50^{\circ} \mathrm{C}$, and 2 min at $60^{\circ} \mathrm{C}$.

149 Sequencing products were precipitated using ExTerminator (A\&A Biotechnology, Gdynia,

150 Poland), and were separated on an ABI PRISM 377 DNA Sequencer (Applied Biosystems,

151 Foster City, CA, USA).

152

153 Sequence edition and alignment

154 Raw chromatograms were evaluated and corrected in Geneious v10. 2.6 (https://www.

155 geneious.com). In order to identify the numts (Bensasson et al., 2001; Song et al., 2008), the

156 mitochondrial COI sequences were translated into amino acid sequences with Geneious v10.2.6

157 using the standard invertebrate mitochondrial genetic code. All of the nucleotide sequences were

158 verified using BLAST searches of NCBI (http://blast.ncbi.nlm.nih.gov/Blast.cgi). The alignment

159 of the sequences that were studied was performed using the MAFFT (Katoh et al., 2002) plugin

160 within Geneious v10.2.6.

161

162 Divergence time estimate

163 We used Praecoris dominicana Poinar, 1991 (Holoptilinae) from Dominican amber that is

164 estimated to be about 15-20 million years old (Iturralde-Vinet \& MacPhee, 1996) as a minimum

165 age constraint. The root was calibrated at 180 Mya based on Ceresopsis costalis Becker-

166 Migdisova, 1958 fossil following Johnson et al. (2018). We applied a lognormal distribution and

167 set a minimum hard bound age by applying an offset value of 15 million years. The secondary

168 calibrating point (MRCA of Holoptilinae and Phymitinae) was selected from Masonick et al.

169 (2017).

170 Divergence times and their confidence intervals were estimated using the Bayesian Markov

171 chain Monte Carlo (MCMC) coalescent method, which was implemented in BEAST version

172 10.0.1 (Suchard et al., 2018). The unlinked GTR model of nucleotide substitution, gamma-

173 distributed rate variation and a proportion of invariant sites of heterogeneity model were applied

174 with their base frequencies estimated during the analysis. A relaxed molecular clock using the

175 uncorrelated lognormal model was applied with a Yule process speciation prior for the branching

176 rates. The final analysis consisted of two independent MCMC chains for 30 million generations 
177 sampling every 1000 generations. The convergence to stationery distribution and the effective

178 population size of the model parameters were checked using Tracer v1.7.1 (Rambaut et al.,

179 2014). The maximum clade-credibility trees were built using TreeAnnotator v1.10.1 (Rambaut \&

180 Drummond, 2002-2018) the initial 10\% of samples were discarded as burn-in. FigTree v1.4.3

181 (http://tree.bio.ed.ac.uk/software/figtree/) was used to visualize the result. The tree was edited 182 and annotated in Corel Draw 17.1.0.572, 2014 Corel Corporation.

183 Morphological data:

\section{Taxon sampling and outgroup}

185 A total of 32 species were included into the dataset with 27 species of the genus Sirthenea.

186 Material in total of over 400 dry specimens was examined for this study. The taxon sampling

187 covered all of the known Sirthenea species that are distributed in almost all of the

188 zoogeographical regions: the Afrotropical region (including Madagascar): S. africana Distant,

189 1903, S. flaviceps (Signoret, 1860), S. picescens Reuter, 1887, S. rodhaini Schouteden, 1913; the

190 Palearctic and Oriental regions: S. caiana Chłond, 2008, S. dimidiata Horváth, 1911, S. flavipes

191 (Stål, 1855), S. kali Chłond, 2018, S. nigronitens (Miller, 1958), S. nitida Chłond, 2008, S. nigra

192 Cai \& Tomokuni, 2004, S. setosa Chłond, 2018; the Australian region: S. laevicollis Horváth,

193 1909, S. obscura (Stål, 1866); the Neotropical region: S. amazona Stål, 1966, S. atra Willemse

194 1985, S. dubia Willemse, 1985, S. ferdinandi Willemse 1985, S. jamaicensis Willemse 1985, S.

195 ocularis Horváth, 1909, S. pedestris Horváth, 1909, S. peruviana Drake \& Haris, 1945, S.

196 plagiata Horváth, 1909, S. stria (Fabricius, 1794), S. venezolana Maldonado Capriles, 1955, S.

197 vidua Horváth, 1909, S. vittata Distant, 1902. The number of Sirthenea species from the New

198 World followed Willemse (1985), the Old World species number followed Chłond (2018). Five

199 species were used as the outgroup taxa; among these, four belonging to the subfamily Peiratinae.

200 Several species of Peiratinae were additionally examined, although the molecular material of

201 those specimens could not be used for the analyses. The taxon sample of the outgroup taxa was

202 limited by the availability of dry specimens whose genetic material could be used in the current

203 research.

204

205

Examination and deposition of the taxa

206 
207 The material is stored in 24 entomological collections. The specimens that were examined during 208 the current studies belong to: CAU - China Agricultural University, Beijing, China; HNHM 209 Hungarian Natural History Museum, Budapest, Hungary; MACN - Museo Argentina de 210 Ciencias Naturales “Bernardino Rivadavia”, Buenos Aires, Argentina; MLPA - Universidad 211 Nacional de La Plata, Museo de la Plata, La Plata, Argentina; MMBC - Moravské Muzeum, 212 Brno, Czech Republic; MNHN - Muséum National d'Histoire Naturelle, Paris, France; MZH -

213 Finnish Museum of Natural History, Helsinki, Finland; NHMB - Naturhistorisches Museum, 214 Basel, Switzerland; NHMD (formerly 'ZMUC') - Natural History Museum of Denmark, 215 Copenhagen, Denmark; NHMUK - Natural History Museum, London, United Kingdom; 216 NHMW - Naturhistorisches Museum Wien, Vienna, Austria; NHRS - Naturhistoriska 217 Riksmuseet, Stockholm, Sweden; NMEG - Naturkundemuseum, Erfurt, Germany; NMPC 218 National Museum, Prague, Czech Republic; NSMT - National Science Museum, Tokyo, Japan; 219 RBINS - Royal Belgian Institute of Natural Sciences; RMCA - Musée Royal de l'Afrique 220 Centrale, Tervuren, Belgium; RMNH - Naturalis Biodiversity Centre, Leiden, The Netherlands; 221 SMF - Forschungsinstitut und Naturmuseum Senckenberg, Frankfurt am Main, Germany; TLMF 222 - Tiroler Landesmuseum Ferdinandeum, Innsbruck, Austria; USMB - Upper Silesian Museum, 223 Bytom, Poland; USNM - National Museum of Natural History, Washington DC, USA; ZJPC -

224 Zdeněk Jindra private collection, Prague, Czech Republic; ZMHB - Museum für Naturkunde der 225 Humboldt-Universität, Berlin, Germany.

226

227

Microscopy and illustrations

228

229

230

231

232

233

234

235

236 237

The characters were examined using a Nikon NiU compound microscope and photographed using a Nikon DS-Fi2 camera. Pictures of the morphological details were taken with NISElements D 4.50.00 64-Bit. Each specimen was imaged from different focal planes via Z-series acquisition and automatically aligned and layered. The drawings were made freehand on a Nikon Eclipse Ni using a camera lucida. The characters of the individuals for the SEM images, which had been sputter-coated with gold in a Pelco SC-6 sputter coater, were imaged using a Phenom XL scanning electron microscope (Phenom-World B.V., Eindhoven, The Netherlands) in low vacuum conditions at a 10,15 and 20 accelerating voltage using a secondary electron detector. The plates were prepared using Corel Draw 17.1.0.572, 2014 Corel Corporation. 


\section{Morphological characters}

239 Since there is no morphology-based phylogenetic analysis targeting the species level

240 relationships within the genus Sirthenea, the first morphological matrix was specifically

241 developed for this study. The morphological characters were scored for both sexes of each

242 species from the different localities of each species (from one to 70 individuals). A total of 64

243 characters were used for the analyses. A matrix of 64 characters (numbered 1-64) across the 32

244 terminal taxa was prepared using Mesquite version 3.5 (Maddison \& Maddison, 2018).

245 Unknown character states were coded with a '?' and inapplicable states were coded with '-'. A

246 csv file containing the character matrix is provided in TableS2.

247 Description, documentation and discussion of the characters (Figs. 1-3) that were used in the

248 analysis as well as the states and their distribution among the analysed taxa refer to the current

249 analysis and are provided below.

250 1. Clypeus: (0) straight, directed horizontally (Fig. 1a); (1) distinctly directed downwards

251

252

253

254

255

256

257

258

259

260

261

262

263

264

265

266

267

268 (Fig. 1b). The apex of the clypeus in most of the studied taxa is directed downward and the state of this character was also seen in all of the outgroup taxa. Among all of the species of Sirthenea, only the Afrotropical species had a straight, horizontally directed clypeus. Both character states were observed in the representatives of Oriental and Neotropical regions. The second state of the character occurred in two species that are distributed in Australia.

2. Point of antennal insertion: (0) in half of the anteocular part of the head (Fig. 1a); (1) near the anterior margin of an eye (Fig. 1b). This character was represented by the second state only in all of the outgroup taxa and Sirthenea ocularis. S. ocularis was the only known species of the genus with strongly enlarged eyes, and as a result, the placement of point of antennal insertion was close to their anterior margin.

3. Apices of antennifers orientation: (0) directed fronto-dorsally (Fig. 1a); (1) directed fronto-ventrally (Fig. 1b). The apices of the antennifers are directed fronto-dorsally in all of the representatives of Sirthenea, and this state of character was also found in more than half of the representatives of the outgroup taxa.

4. Dorsal surface of antennifers: (0) smooth; (1) with a distinct sculpturation (corrugated and pointed) (Fig. 1c). Sculpturation on the dorsal surface of the antennifers is a character that was present in all of the known Oriental and Australian species of Sirthenea as well 
as in the S. picescens that is distributed in Madagascar. This character is also present in some Oriental species and in some of the outgroup taxa.

5. Mandibular plates: (0) small (Fig. 1b); (1) large (Fig. 1j). The mandibular plates of all of the Sirthenea species as well as in all of the studied taxa belonging to the subfamily Peiratinae (except Androclus Stål, 1863) were relatively small. Distinctly enlarged mandibular plates, compared with those seen in representatives of Sirthenea, were present in the outgroup genera Androclus and Platymeris Laporte, 1833.

6. Shape of scape: (0) club shaped (Fig. 1c); (1) slender (Fig. 1b). The first state of the character was present in most of the representatives of Sirthenea. An elongate and slender scape was characteristic only for four species of Sirthenea: the Australian species as well as the Madagascan $S$. picescens and the Oriental S. setosa as well as most of the outgroup taxa.

7. Length of scape: (0) short, not surpassing the apex of the head; (1) long, surpassing the apex of the head (Fig. 1c). Among the representatives of Sirthenea, the second state of the character was present in only three species: S. picescens, S. laevicollis and $S$. jamaicensis. An elongate scape, surpassing the apex of the head was a diagnostic character to support the placement of the first two above-mentioned species in a distinct subgenus Monogmus Horváth, 1909.

8. Length of pedicel: (0) shorter than the head; (1) equal or longer than the head (Fig. 1b). A short pedicel occurred in all of the Sirthenea species and in only four of the outgroup taxa.

9. Length of labial segment II: (0) short (distinctly shorter than labial segment III) (Fig. 1a); (1) long (almost the same length as labial segment III) (Fig. 1j). Short labial segment II is a state that was present in all of the representatives of Sirthenea as well as in most of the outgroup taxa. The length of labial segment II was equal or almost equal to labial segment III only in Platymeris rhadamanthus Gerstaecker, 1873.

10. Position of the apex of labial segment III: (0) not reaching the anterior margin of the anterior pronotal lobe of the pronotum (Fig. 1a); (1) reaching the anterior margin of the anterior pronotal lobe of the pronotum (Fig. 2g). The first state of this character was observed in all of the Sirthenea species except $S$. setosa. The condition of this character 
in S. setosa (labial segment III reaching the anterior margin of the pronotum) was a result

300

301

302

303

304

305

306

307

308

309

310

311

312

313

314

315

316

317

318

319

320

321

322

323

324

325

326

327

328 of the segment length.

11. Condition of basal part of labial segment III: (0) not expanded (Fig. 1a); (1) expanded (Fig. 2g). The second state of the character was present in all of the Afrotropical and Australian species. Only three of the species distributed in Oriental region $(S$. nigronitens, $S$. nigra and $S$. setosa) and most of the Neotropical species did not have an expanded basal part of the segment.

12. Ventral surface of basal part of labial segment III: (0) not flattened (Fig. 1d); (1) flattened (Fig. 1j). The ventral surface of the basal part of labial segment III in all of the Sirthenea and most of the outgroup taxa was not flattened. Only six of the studied outgroup taxa had a distinctly flattened basal part of the ventral surface of labial segment II.

13. Shape of labial segment IV: (0) thin (Fig. 1a); (1) robust (Fig. 1j). The first state of the character occurred in all of the Peiratinae and it was common in most of the Reduviidae. The state (1) was an autapomorphy for P. rhadamanthus.

14. Size of an eye in lateral view: (0) not reaching the dorsal and ventral ridges of the head (Fig. 1b); (1) reaching the dorsal and ventral ridges of the head (Fig. 1d).

15. Eye width: (0) narrower than the synthlipsis (Fig. 1c); (1) same width or wider than the synthlipsis. The width of an eye was evaluated in the dorsal view. The first state was present in the Sirthenea species that are distributed in Afrotropical region and most of the species from the Oriental region (except $S$. nigra and $S$. setosa). Most of the Neotropical species had the second state of this character.

16. Shape of posterior margin of an eye: (0) S-shape (Fig. 1a); (1) U-shape (Fig. 2g); (2) rounded (without a cavity) (Fig. 1b). To code two different shapes of the posterior margin of an eye in the lateral view as well the absence of a cavity of the margin, we treated them as one multistate character.

17. Ventral margin of the head: (0) convex (Fig. 1a); (1) straight or concave (Fig. 1d). The ventral margin of the head was convex in most species of Sirthenea (especially in the species that are distributed in South-East Asia and Australia) as well as in most of the outgroup taxa. 
18. Posteroventral part of the head: (0) at same level as the ventral ridge of the neck-like part of the head; (1) lower than the ventral ridge of the neck-like part of the head (Fig. 1d). The first state of this character was present in most of the Sirthenea species (every Afrotropical species) as well as in the outgroup taxa.

19. Apodeme depression on the head: (0) shallow (Fig. 1c); (1) deep (Fig. 1h). Among the representatives of Sirthenea only two species S. setosa (Oriental region) and S. laevicollis (Australian region) had a deep apodeme depression on the head, while it was common character in the outgroup taxa.

20. Degree of the depression of transversal furrow of the head: (0) shallow (Fig. 1c); deep (1) (Fig. 1h). A shallow transversal furrow of the head was present in the Afrotropical and some of the Oriental representatives of Sirthenea. A deep furrow was characteristic for the Australian and Neotropical (except S. jamaicensis) species.

21. Shape of the transversal furrow of the head: (0) triangular (Fig. 1i); (1) rounded (Fig. 1c). The shape of the transversal furrow of the head was unified (triangular) only in the Afrotropical species of Sirthenea.

22. Ocelli: (0) present (Fig. 1a); (1) absent. Lack of ocelli only occurred in one species, $S$. $k a l i$, which is known only from brachypterous females. Shortened wings are often connected with the absence of ocelli, however, the ocelli that were present in the brachypterous females that were found in three other species: S. rodhaini, S. dimidiata and S. laevicollis. This character was an apomorphy for S. kali.

23. Postocular part of the head: (0) equal to or lower than the anteocular part in the lateral view; (1) distinctly elevated compared to the anteocular part in the lateral view (Fig. 1d). This character was coded as (0) only in the African representatives of Sirthenea. The second state of the character was uniform in the representatives of the Australian region.

24. Postocular enlargement of the head: (0) absent; (1) present (Fig. 1f). Among the Sirthenea only $S$. jamaicensis had an enlargement behind the posterior margin of an eye, however, it was a characteristic structure for most of the outgroup Peiratinae.

25. Lateral processes on the neck-like part of the head: (0) absent; present (1) (Fig. 1f). This character was coded (1) in most of the outgroup taxa that belong to Peiratinae. This structure was absent in the representatives of Sirthenea. 
359

360

361

362

363

364

365

366

367

368

369

370

371

372

373

374

375

376

377

378

379

380

381

382

383

384

385

386

387

388

389

26. Length of the anterior pronotal lobe of pronotum: (0) longer than the posterior pronotal lobe of the pronotum (Fig. 1i); (1) shorter than the posterior pronotal lobe of the pronotum (Fig. 1j). The second state of this character was present only in $P$. rhadamanthus.

27. Width of the anterior pronotal lobe of pronotum in males: $(0)$ similar width as the posterior pronotal lobe of the pronotum; (1) distinctly narrower than the posterior pronotal lobe of the pronotum (Fig. 1i). This character was based on the measurements of the anterior and posterior lobes of the pronotum and it was uniformly coded (as 1) only in the Australian representatives of the genus. In line with the findings or previous taxonomic studies, the females of Sirthenea were larger than the males and the width of their anterior lobe of the pronotum was similar to the width of the posterior lobe.

28. Collar of pronotum: (0) reduced; (1) distinctly separated (Fig. 1g). Our studies recovered two different states of this character in Sirthenea. A distinct collar was present in all of the Neotropical and Australian representatives of the genus. Two states of this character were recognised as being a diagnostic feature of the Afrotropical and Oriental species of Sirthenea.

29. Anterolateral angles of collar of pronotum: (0) not enlarged; (1) distinctly enlarged (Fig. 1g). The enlargements of the anterolateral angles of the pronotum in the Australian and most of the Neotropical species of Sirthenea as well as in almost all of the outgroup taxa were very distinct.

30. Sulci of anterior the pronotal lobe: (0) distinct (Fig. 1i); (1) reduced (Fig. 1g). The second state of the character was present only in two species: S. picescens and $S$. laevicollis. A reduced sulci of the anterior lobe of the pronotum was the second diagnostic character to support the placement of the first two above-mentioned species in the subgenus Monogmus and it was also present in three other species from the outgroup taxa belonging to the subfamily Peiratinae.

31. Shape and length of apodeme depression of anterior pronotal lobe: (0) long and thin (Fig. 1g); (1) short and wide (Fig. 1i). Most of Sirthenea species possess long and thin apodeme depression of pronotum.

32. Anterior pronotal lobe spinelike processes: (0); (1) present (Fig. 1j). This character was present in only one outgroup taxon $-P$. rhadamanthus. 
390

391

392

393

394

395

396

397

398

399

400

401

402

403

404

405

406

407

408

409

410

411

412

413

414

415

416

417

418

419

420

33. Shape of transversal furrow of the pronotum latero-external sulci: (0) not curved; (1) curved (Fig. 1i). A curved transversal furrow in the place of connection with lateroexternal sulci occurred in many species of Sirthenea that were distributed in various zoogeographical regions.

34. Posterior pronotal lobe: (0) smooth; (1) distinctly sculptured or pointed (Fig. 1i). In most species of Sirthenea, the posterior pronotal lobe was smooth as opposed to the outgroup taxa where most of the species had a distinct sculpture on this structure.

35. Posterior margin of the posterior pronotal lobe: (0) without a cavity (Fig. 1i); (1) with a distinct cavity (Fig. 1e). This character is coded as (0) for all of the studied species except for S. amazona, which had a unique, very distinct cavity.

36. Spine-like processes on the postolateral angles of the posterior pronotal lobe of the pronotum: (0) absent; (1) present (Fig. 2a). This character was similar to character 32 and was also present exclusively in $P$. rhadamanthus.

37. Stridulitrum: (0) not elongated anteriorly; (1) elongated anteriorly (Fig. 1j). An anteriorly elongated stridulitrum was present only in $P$. rhadamanthus; this state was absent in all of the studied genera of Peiratinae.

38. Prosternal process: (0) elongated (Fig. 1a); (1) short. The prosternal process in all of the studied Peiratinae was long and distinctly surpassed the fore coxae. Only in $P$. rhadamanthus was it relatively short and did not surpass the posterior margin of the procoxal cavity.

39. Ridges of the proepisternum and proepimeron: (0) connected along the entire length (Fig. 1j); (1) not connected along the entire length (Fig. 1a). This character was coded as (0) in all of the African, Australian and most of the Neotropical species of Sirthenea. The same state of character was observed in most of the outgroup taxa.

40. Posterior angles of the dorsolateral part of metapleura: (0) arcuate; (1) bent at a right angle (Fig. 2b); (2) depressed (Fig. 1j). This multistate character was coded as (2) only in $P$. rhadamanthus. Arcuate angles of the metapleura were present in all of the African representatives of Sirthenea as opposed to the state of the same character in almost all of the species from the New World (except $S$. jamaicensis).

41. Metapleura: (0) with two complete ridges; (1) with one complete ridge (Fig. 2b). This character was coded (1) for all of the species of Sirthenea from Australian and 
421

422

423

424

425

426

427

428

429

430

431

432

433

434

435

436

437

438

439

440

441

442

443

444

445

446

447

448

449

450

451

Neotropical regions as well as most of the Afrotropical and Oriental regions. Only three species of outgroup taxa had two complete ridges of the metapleura.

42. Fore coxae: (0) elongated (Fig. 1a); (1) not elongated. This feature coded as (0) in all of the Peiratinae and was used as one of the main diagnostic characters of this subfamily.

43. Presence of the fossula spongiosa on the middle tibia: (0) absent; (1) present (Figs. 2c, d). The fossula spongiosa is a hairy structure on the tibiae that occurs in many Reduviidae. This structure shows a substantial homoplasy within the Reduviinae and it was treated as a plesiomorphic feature. Zhang et al. (2016) found evidence for a single origin of this structure in Reduvioidea with numerous reductions. Among all of the species of Sirthenea, this feature was present only on the middle tibia of S. laevicollis. The fossula spongiosa on the middle tibia was also present in all of the outgroup taxa.

44. Length of the fossula spongiosa on the fore tibia: (0) longer than half of length of tibia (Fig. 2f); (1) equal or shorter than half of length of tibia (Fig. 2e). Only three species of Sirthenea had a short fossula spongiosa on fore tibia.

45. Brachyptery in females: (0) absent; (1) present (Fig. 3c). The previous study documented brachyptery in the genus Sirthenea for the first time. Brachypterous females were found in six species: S. rodhaini, S. dimidiata, S. kali, S. laevicollis, S. jamaicensis and $S$. vidua; the last four species are known exclusively from brachypterous females. Among the outgroup taxa, only the females of Ectomocoris ululans (Rossi, 1807) were brachypterous.

46. Basal part of the clavus: (0) median longitudinal groove absent; (1) median longitudinal groove present (Fig. 2j). This character was coded (1) in the $S$. kali from the Oriental region; however, a longitudinal groove on the clavus was present in most of the New World species of Sirthenea.

47. Depression on the basal half of the clavus: (0) absent; (1) present (Fig. 21). This character was present in a few species of Sirthenea.

48. Width of the clavus: (0) equal to the cell formed by the cubital and postcubital veins (Fig. 2a); (1) distinctly wider than the cell formed by the cubital and postcubital veins (Fig. 2h). The second state of this character was found only in Ectomocoris ululans.

49. Apical internal cell surface: (0) less than half of the surface of the apical external cell (Fig. 2i); (1) more than half of the surface of the apical external cell (Fig. 2h). A small 
452

453

454

455

456

457

458

459

460

461

462

463

464

465

466

467

468

469

470

471

472

473

474

475

476

477

478

479

480

apical internal cell was observed in all of the Sirthenea species as opposed to the outgroup taxa, in which only Calistocoris virgo (Miller, 1940) had a small apical internal cell, and the state of this feature (1) was dominant.

50. Shape of the apical internal cell: (0) quadrilateral (Fig. 2i); pentagonal (Fig. 2h). The pentagonal apical internal cell was present only in S. laevicollis and four species of the outgroup taxa.

51. Cu vein: (0) curved (Fig. 2h); (1) straight (Fig. 2i). The vein was straight in only four representatives of Sirthenea (distributed in the Oriental and Neotropical regions).

52. Length of the apex of the scutellum: (0) short (Fig. 2k); (1) elongated (Fig. 2j). An elongated apex of scutellum was present in all of the Oriental, Australian and Neotropical species of Sirthenea as well as in S. picescens (Afrotropical region) and S. setosa (Oriental region). Only three taxa from the outgroup had a short apex of the scutellum.

53. Apex of the scutellum: (0) directed horizontally; (1) directed vertically (Fig. 1j). The only representatives with a vertically directed apex of the scutellum were the species from the outgroup taxa.

54. Depression on the scutellum: (0) triangular (Fig. 2k); (1) tongue-like (Fig. 2j). This character was coded (1) in most of the analysed taxa. Among the Sirthenea, only a few species from Afrotropical and Oriental regions had a triangular depression on the scutellum.

55. Lateral spine-like processes of the scutellum: (0) absent; (1) present (Fig. 2a). This character was present only in P. rhadamanthus. This feature was common in representatives of the subfamily Reduviinae.

56. Lateral angles of the basal part of the scutellum: (0) rounded (Fig. 2k); tightened (Fig. $2 \mathrm{j}$ ). This feature was coded (0) in all of the Afrotropical and Oriental species of Sirthenea with the exception of S. caiana. The species that are distributed in the Australian and Neotropical regions had tightened lateral angles of the scutellum.

57. Lateral depressions of the basal part of the scutellum: (0) shallow (Fig. 2k); (1) deep (Fig. 2j). Shallow lateral depressions of the scutellum were characteristic only for the Afrotropical species of Sirthenea and S. amazona. 
481

482

483

484

485

486

487

488

489

490

491

492

493

494

495

496

497

498

499

500

501

502

503

504

505

506

507

508

509

510

511

58. Connexives orientation: (0) vertical (Fig. 1j); horizontal (Fig. 2h). The first state of this character was present in all Sirthenea species but also occurred among the coded outgroup taxon - C. virgo.

59. Distance of spiracles III-IV from the ventral connexival suture: (0) distant (Fig. $2 \mathrm{~m}$ ); (1) connected (Fig. 2n); (2) fused (Fig. 2o). Distance of the abdominal spiracles from the ventral connexival suture was combined into one multistate character, and it as coded as (2) only in only two representatives of Sirthenea: S. nitida and S. ocularis.

60. Posterior margin of the VIII abdominal sterna of males: (0) without an indentation (Fig. 3a); (1) with an indentation (Fig. 3b). The Sirthenea species that are distributed in the Afrotropical, Oriental (except S. kali and S. nigronitens, which are known only from females) and the Australian regions had a distinct indentation on the VIII abdominal sterna of males. Neotropical species of the genus were devoid of such a structure.

61. Parameres: (0) symmetric (Fig. 3h, i); (1) asymmetric (Fig. 3d-g). All of the representatives belonging to the subfamily Peiratinae were characterised by asymmetric parameres.

62. Shape of the parameres: (0) club-shaped (Figs. 3d, e); (1) wide (Fig. 3f, g); (2) narrow (Figs. 3h, i). This multistate character was coded (2) only in the case of P. rhadamanthus. Among the Sirthenea, most of the species had very characteristic, club-shaped parameres. The only exceptions were both of the species that are distributed in Australia: $S$. laevicollis and S. obscura as well as the Oriental S. setosa and Madagascan S. picescens.

63. Additional process on the VII abdominal sterna of males: (0) absent; (1) present (Fig. 3b). This character was present in only one outgroup taxon - Peirates strepitans Rambur, 1839.

64. Median process of the pygophore: (0) short (Fig. 3j); (1) long (Fig. 3k); (2) bulbous (Fig. 31). A long median process of the pygophore was present in all of the outgroup taxa belonging to the subfamily Peiratinae and in both species that are distributed in Australia: S. laevicollis and S. obscura as well as the Oriental S. setosa and the Madagascan $S$. picescens. This species had a presence that was similar to feature 62 . The only species with a bulbous median process of the pygophore was $S$. nigra. 


\section{Phylogenetic analyses:}

513 A combined matrix of the molecular (939 bp) and morphological (64 characters) data for the 514 total number of taxa under study (32) was analysed using the Bayesian Inference (BI) method.

515 Separate analyses of molecular and morphological datasets were also performed. Gaps were 516 treated as missing data in all of analyses.

517 The alignment was initially partitioned by gene and for protein-encoding genes, by position. The 518 optimal partitioning scheme and the corresponding models of nucleotide evolution were 519 determined using PartitionFinder v. 2.1.1 (Lanfear et al., 2016) using the Bayesian Information 520 Criterion. Only models for "mrbayes" were considered, the branch lengths were unlinked and the 521 search was set to the "greedy" algorithm (Lanfear et al., 2012). The morphological data in the 522 combined matrix were analysed as a single, separate partition using the maximum likelihood 523 model for the discrete morphological character data under the assumption that only characters 524 that varied among the taxa were included (Mkv) (Lewis, 2001). Bayesian analyses were 525 performed using MrBayes v3.2.6 (Ronquist et al., 2012) running on a CIPRES Science Gateway 526 v3.3 (phylo.org). All analyses used four chains (one cold and three heated) and two runs of 30 527 million generations with default prior settings. The analyses were conducted with a gamma 528 distribution for the morphological partition. Convergence of both runs was visualised in Tracer 529 v1.6 (Rambaut et al., 2014) as well as by an examination of the PSRF values and average 530 standard deviation of the split frequencies in the MrBayes output.

531 Trees were edited and annotated in Corel Draw 17.1.0.572, 2014 Corel Corporation.

532 Nodes with $(\mathrm{BI})$ posterior probability $(\mathrm{PP})>0.95$ were considered to be strongly supported, 533 with $\mathrm{PP}=0.90-0.94$ moderately supported, and with $\mathrm{PP}=0.85-0.89$ (0.80-0.89 in morphology534 based analysis) weakly supported. Nodes with $\mathrm{PP}<0.85$ (or 0.80 ) were considered to be 535 unsupported.

536

\section{Results}

\section{Divergence time estimate}


541 The age estimates (median age values and 95\% Highest Posterior Density (HPD)) from the

542 BEAST analysis are presented in Fig. 4 According to the relaxed molecular clock analysis of the 543 molecular data, the genus Sirthenea started diverging in the Late Cretaceous (74,83 Mya, 95\%

544 HPD 109,3-43,8 Mya) into two clades. The clades began to branch in the Paleocene. The first

545 clade diverged 65,87 Mya (node A, 95\% HPD 98-38,5 Mya) and comprises S. nigra, $S$.

546 dimidiata, S. flaviceps, S. caiana, S. rodhaini, S. flavipes, S. picescens and S. africana. The

547 second clade diverged 62,1 Mya (node B, 95\% HPD 93,6-35,5 Mya) and is formed by $S$. atra, $S$.

548 obscura, S. nitida, S. peruviana, S. pedestris, S. kali, S. laevicollis, S. setosa, S. vittata, S.

549 ocularis, S. nigronitens, S. jamaicensis, S. dubia, S. ferdinandi, S. plagiata, S. vidua, S.

550 venezolana, S. stria and S. amazona. Together with species from the genus Sirthenea, four

551 species from other genera from the subfamily Peiratinae and Platymeris rhadamanthus from the

552 subfamily Reduviinae also branched. Most species of the investigated genus came into existence

553 in the Neogene.

\section{Phylogenetic analyses:}

555 The Bayesian Inference (BI) analysis reached convergence with the average standard deviation

556 of split frequencies that was well below 0.01. The mixing of the MCMC chains was good since

557 the effective sample sizes (ESS) for the posterior probability were much higher than 200 and the

558 observed potential scale reduction factor (PSRF) was 1.00. The results of molecular datasets

559 analysed separately are shown in Figs 5 and 6, respectively, while the tree resulting from the

560 combined analysis is shown in Fig. 7.

561 The total evidence analysis (Fig. 7) recovered the genus Sirthenea polyphyletic with all of the

562 outgroup genera, except for Platymeris and Androclus resolved within one clade. The position of

563 the Sirthenea africana + Androclus granulatus Stål, 1863 clade was unresolved. All other

564 Sirthenea species and representatives of Peirates Serville, 1831, Calistocoris Reuter, 1881, and

565 Ectomocoris Mayr, 1865 were resolved together, although without a support and consisted of

566 two well supported clades. The first clade consists of Sirthenea flavipes, S. flaviceps, S. rodhaini,

567 S. caiana, S. nigra and S. dimidiata $(\mathrm{PP}=1)$ with Peirates strepitans recovered as a sister with a

568 strong support ( $\mathrm{PP}=0.99)$. All of the other Sirthenea species formed a monophylum along with

569 the species of the genera Calistocoris, and Ectomocoris with strong support $(\mathrm{PP}=1)$. Within this 570 clade, the Sirthenea picescens and Ectomocoris ululans species branched off first. Next, the $S$. 
571 amazona was recovered to be sister to $S$. stria + S. venezolana clade $(\mathrm{PP}=0.97)$ and all together

572 sister to a very well-supported monophylum consisting of the remaining species of this clade and 573 species of Calistocoris $(\mathrm{PP}=0.99)$. In this clade, Calistocoris virgo was recovered sister to the

574 Sirthenea species with strong support $(\mathrm{PP}=1)$.

575 The results of analyses of the morphological (Fig. 5) and molecular (Fig. 6) data separately were 576 not congruent and the major difference was the monophyly of Sirthenea. While the results of 577 molecular-based analysis were largely congruent with the results of the combined analysis, the 578 morphology-only analysis recovered Sirthenea as monophyletic with low support (0.82). All of 579 the outgroup genera, except for Calistocoris were unresolved, while Calistocoris virgo was 580 recovered as sister to Sirthenea without a support.

581

\section{Discussion}

583

584 Our results are the first comprehensive analysis concerning one of the representatives of the 585 subfamily Peiratinae. A phylogeny and molecular analysis of the genus Sirthenea that is based on a worldwide sampling has been missing to date. The morphological and molecular analyses of 27 known species of Sirthenea and five outgroup taxa (four Peiratinae and one Reduviinae) allowed us to integrate the phylogenetic relationships and the Sirthenea time tree with the spatial history in the context of palaeogeography (Sanmartin and Ronquist, 2004; McIntyre et al., 2018). We also verified a correlation of the divergence dates (Fig. 4) based on the molecular clocks of all known Sirthenea species that belong to the geographically separated taxa. As biogeographic history is also far too complex to be inferred from ancestral reconstructions alone, our interpretations are derived from the joint molecular dating, morphological analysis and the phylogenetic patterns within clades (Figs 1-7) as well as specific geological periods. Our results suggest that the evolution of Sirthenea is considerably complex and cannot be limited to a sequence of dispersal and vicariance events. However, because the diversity of the genus and the young age of some of the species (Fig. 4) we cannot exclude that dispersal could also played a role in the processes that have shaped the global distribution of Sirthenea, what we have demonstrated in our previous studies (Chłond et al., 2017). The molecular clock data indicate that most of the known species are dated at the beginning of Paleogene 74-61 Mya (Fig. 4). The 601 clade A comprising species S. africana, S. caiana, S. dimidiata, S. flavipes, S. nigra, S. flaviceps, 
602 S. picescens, $S$. rodhaini, as well as the clade B: S. kali, S. nigronitens, S. nitida, S. setosa, $S$.

603 laevicollis, S. obscura, S. amazona, S. atra, S. dubia, S. ferdinandi, S. jamaicensis, S. ocularis, $S$.

604 pedestris, S. peruviana, S. plagiata, S. stria, S. venezolana, S. vidua and S. vittata (Fig. 4)

605 diverged about 75 Mya. Our results show that $S$. picescens is one of the oldest species in the

606 genus. Conversely, the molecular data provide evidence that the youngest species is $S$. flavipes

607 (9,17 Mya), which, can be treated as a model species, thus partially confirming the role of

608 dispersion and allopatric speciation within the representatives of Sirthenea (Chłond et al., 2017).

609 Molecular clock also revealed that the main radiation of Sirthenea lasted from Eocene to the

610 mid-Miocene, 46-13 Mya (Fig. 4). The incongruence between the results of molecular (including

611 combined) (Figs. 6, 7) and morphological analyses (Fig. 5) is not uncommon issue (Wieczorek et

612 al., 2017; Tang et al., 2018) as both data source often suggest conflicting results. We carefully

613 evaluated a possibility of either splitting Sirthenea into several genera, or including the other

614 genera into our studied genus. Both possibilities, though, seem to be premature as the genus is

615 clearly diagnosable by several morphological synapomorphies, e.g. lack of fossula spongiosa on

616 middle tibiae, orientation of apices of antenniferes, distinctly elongated head (mostly anteocular

617 part), shape of the head, orientation of apical part of the head. We hypothesize that the resulting

618 polyphyly recovered by molecular data analyses are a result of limited gene sampling rather that

619 true non-monophyly. Undoubtedly, this calls for further studies and addition of other gene

620 markers is planned for the near future. Nevertheless, the obtained results encouraged us to

621 discuss possible scenarios of evolutionary history of the particular lineages currently classified as

622 the genus Sirthenea.

623 As we did not find any other known worldwide distributed genus among Peiratinae (Chłond \&

624 Bugaj-Nawrocka, 2015), there is a possibility, which is supported by geological, bioclimatic and

625 environmental events (Couvreur et al., 2011; Baker and Couvreur, 2013; McIntyre et al., 2018),

626 that the distribution of Sirthenea may be the result of a change of the microhabitat it occupied.

627 An analysis of the climatic preferences in various ecoregions (Chłond \& Bugaj-Nawrocka, 2015)

628 suggested that the representatives of the genus are mainly linked to tropical and temperate

629 climates that have tree vegetation such as the tropical and subtropical moist broadleaf forests

630 biomes, temperate broadleaf biomes and mixed forest biomes that are widespread in Africa,

631 South Asia, southern North America and the northern parts of South America and Australia. A

632 reconstruction of the biogeographic history indicated that these types of ecological niches 
633 initially diversified during the mid-Cretaceous around 100 Mya at the northern and middle

634 latitudes on the supercontinent of Laurasia (Upchurch \& Wolf, 1987; Davis et al., 2005;

635 Couvreur et al., 2011; Baker \& Couvreur, 2013; Couvreur \& Baker, 2013). Palaeoflora that is

636 attributable to similar niches was found in the early Paleocene of North America (Johnson \&

637 Ellis, 2002) and the late Paleocene of South America (Jaramillo et al., 2006, 2010; Wing et al.,

638 2009) and Africa (Raven \& Axelrod, 1974; Morley, 2000; Jacobs, 2004). These facts are

639 congruent with our results: South American, Australian and part of Asian species grouped into

640 one clade B, and Madagascan, some of the African and Asian species grouped into clade A (Fig.

641 4). As the origin of most Sirthenea species is dated at the beginning of Paleogene 74-61 Mya

642 (Fig. 4) we can conclude, that the genus is of South origin, and was probably undivided until

643 African-Madagascan-Indian plates separated from Antarctica-Australian-South American plate.

644 The direction of dispersal was most likely from drifting Africa to Madagascar, India and

645 continental Asia, and from South America to Australia and Asia. In this case, the molecular

646 phylogeography of the genus is consistent with the phylogeography of other group of insects

647 (Sklenarova et al., 2013; Ye et al., 2018) The faunal links between South America and Australia

648 are presumably due to the long period of geological contact between those continents via

649 Antarctica (Ye et al., 2018). The biogeographic relationships among the fauna of the

650 southeastern tropics (Africa, Madagascar, India and Southeast Asia) are explained as being the

651 result of a recent dispersal along the coasts of the Indian Ocean (Sklenarova et al., 2013).

652 Exchanges between the eastern landmasses have been frequent since the collision of the

653 Australian and Asian plates in the Miocene (Sanmartin \& Ronquist, 2004; Ye et al., 2018,

654 McIntyre et al., 2018) and the creation of Wallacea. Wallacea in its present form is a relatively

655 young configuration of islands between Asia and Australia and the Australian and Oriental

656 lineages could use this dispersal route since the Australian plate approached Asia 20-15 mya

657 (Sklenarova et al., 2013; Chłond et al., 2017). Although this route provided limited dispersal

658 opportunities, our analysis revealed two relatively young species (Fig. 4) in this area: $S$.

659 nigronitens (New Guinea) and S. setosa (Malesia-Borneo).

660 While evaluating the phylogeny of Sirthenea (Figs. 5, 6, S3), we found that the fossula

661 spongiosa and its development seems to be one of the most important morphological characters,

662 most likely associated with the ecological niche that is inhabited which would support our

663 hypothesis (Livingstone \& Ambrose, 1984; Zhang et al., 2016b). The mentioned structure is a 
664 cushion-like expanded area on the tibia that is composed of thousands of minute hairs (Figs. 2c-

665 f), and the basic function of this structure is a prey capture (Weirauch, 2007, 2008; Zhang et al., $6662016 \mathrm{a}, \mathrm{b})$. We found that the fossula spongiosa is present on the fore and middle tibiae in all 667 Peiratinae, while in Sirthenea, it is only present on fore legs - with exception of S. laevicollis, 668 which is distributed exclusively in Australia. The development of the fossula spongiosa on the 669 fore tibia is considered here as a reduction (in relation to other Peiratinae) and should be treated 670 as an apomorphy for the Sirthenea. It has been suggested that these losses may be correlated with 671 the evolution of a raptorial type of legs (Livingstone \& Ambrose, 1984; Weirauch, 2007; Zhang 672 et al., 2016b). In the non-specialised predators (in terms of prey), this type of reduction, as well 673 as strongly enlarged fore femurs and tibiae, suggests that only the fore legs are used to grip prey, 674 which may possibly indicate a correlation with capturing the prey from hiding. Studies on 675 various types of raptorial legs suggest that the loss of the fossula spongiosa is not directly 676 correlated with the evolution of alternative types of raptorial legs, but may be associated with the 677 type of prey, predatory behaviour, salivary toxicity and the morphological adaptations that pose 678 intricate and interrelated factors that have influenced the evolution of leg structures (Zhang et al., 679 2016b). Moreover, comparative studies of the fossula spongiosa provide evidence that this 680 structure has a direct impact on the efficiency of capturing prey in their ecosystems. The 681 development of the fossula spongiosa is also related to the gradual transformation of tropical 682 rainforests (reduction) into scrub jungles and semiarid zones (strong development) (Livingstone $683 \&$ Ambrose, 1984).

684 Tropical and subtropical moist microhabitats, with an abundance of litter fauna that provide a 685 rich variety of prey and proper habitat conditions on the ground (leaves, elements of trees, 686 stones), indicate the presence of a ground-dwelling predator such as Sirthenea with reduced 687 fossula spongiosa, and preys on other insects in this particular environment. In contrast, the 688 maximum extent of the fossula spongiosa development in other genera of Peiratinae (e.g. 689 Ectomocoris - with an extremely developed fossula spongiosa (Fig. 2f)) is characteristic for 690 species that live in scrub jungles and semiarid zones. A scarcity of prey in these ecosystems 691 forced adaptations that prevent any vagrant prey from escaping the firm grip of the fossula 692 spongiosa (Livingstone \& Ambrose, 1984). The presence of this structure on the middle tibia 693 that is only observed in S. laevicollis is probably connected with living in more arid niches 694 (Chłond \& Bugaj-Nawrocka, 2015) than those that are inhibited by other representatives of the 
695 genus. The molecular clock shows that $S$. laevicollis is one of the youngest species of the genus 696 (Fig. 4), which seems to confirm that the occurrence of the fossula spongiosa on the middle 697 tibiae is an autapomorphy for this relatively young species, whose ancestor branched off after the 698 separation of Australia (Ye et al., 2018, McIntyre et al., 2018). The results of previous studies 699 (Livingstone \& Ambrose, 1984; Zhang et al, 2016b) seem to confirm our hypothesis about the 700 evolutionary history of Sirthenea. The loss of the fossula spongiosa on the middle tibia was 701 probably connected with a change and/or adaptation to newly formed, more humid ecological 702 niches (Morley, 2000; Johnson \& Ellis, 2002; Jacobs, 2004; Jaramillo et al., 2006, 2010; 703 Couvreur et al., 2011; Baker \& Couvreur, 2013), characterized with variety of prey and a low 704 level of competition. This kind of niches could be colonized by different predatory insects that 705 were able to adapt to life in such ecosystems.

706

\section{Conclusions}

708 The results of our estimations of divergence times are consistent with the results that have been 709 obtained by other researchers (Hwang \& Weirauch, 2012; Zhang et al., 2016a). The combination 710 of the estimations of divergence times and a total-evidence analysis (present studies), as well as a 711 model of the range of distribution (Chłond \& Bugaj-Nawrocka, 2015) that is connected with the 712 reconstructions of biogeographic history of Earth (Couvreur et al., 2011; Baker \& Couvreur, 713 2013; Couvreur \& Baker, 2013; Ye et al., 2018; McIntyre et al., 2018), indicate that future 714 analyses should focus mostly on biogeographic reconstructions to support our hypothesis.

715 Further phylogenetic studies of all of the known genera of subfamily Peiratinae are required in 716 order to understand the relationships within subfamily (Weirauch \& Munro, 2009; Hwang \&

717 Weirauch, 2012; Zhang et al., 2016a, b). The present studies complement our knowledge about 718 Sirthenea and should be considered as the beginning of the phylogenetic exploration of the 719 genus. As its distribution (Chłond \& Bugaj-Nawrocka, 2015) and taxonomy (Willemse, 1985;

720 Chłond, 2018) are already well known and we provide the preliminary phylogeny of Sirthenea,

721 the next step should be an increased taxon and gene sampling to resolve the questions of

722 Sirthenea non-monophyly and its systematic position within Peiratinae.

\section{References}


725

726

727

728

729

730

731

732

733

734

735

736

737

738

739

740

741

742

743

744

745

746

747

748

749

750

751

752

753

754

Baker WJ, Couvreur TLP. 2013. Global biogeography and diversification of palms sheds light on the evolution of tropical lineages. I. Historical biogeography. Journal of Biogeography 40:274-285

Bensasson D, Zhang D-X, Hartl DL, Hewitt GM. 2001. Mitochondrial pseudogenes: evolution's misplaced witnesses. Trends in Ecology and Evolution 16:314-321

Cai W, Taylor SJ. 2006. Lentireduvius, a new genus of Peiratinae from Brazil, with a key to the New World genera (Hemiptera: Reduviidae). Zootaxa 1360:51-60

Cai W, Tomokuni M. 2004. Taxonomic notes on Vietnamese Peiratinae with description of a new species (Hemiptera: Reduviidae). Oriental Insects 38:85-94

Chłond D. 2008a. A new species of Sirthenea Spinola, 1840 (Heteroptera: Reduviidae: Peiratinae) from Laos. Oriental Insects 42:385-389

Chłond D. 2008b. A new species of Sirthenea Spinola (Heteroptera: Reduviidae: Peiratinae) from Vietnam. In: Borowiec, L. \& Tarnawski, D. (Eds) The importance of natural history museum of taxonomy. Polish Taxonomical Monographs, Wrocław 15:139-146

Chłond D. 2018. A taxonomic revision of the genus Sirthenea (Hemiptera: Heteroptera: Reduviidae) of the Old World. Zootaxa 4520(1):1-85. https://doi.org/10.11646/zootaxa.4520.1.1

Chłond D, Bugaj-Nawrocka A. 2015. Distribution pattern and climate preferences of the representatives of the cosmopolitan genus Sirthenea Spinola, 1840 (Heteroptera: Reduviidae: Peiratinae). PLoS ONE 10(10):e0140801 https://doi.org/10.1371/journal.pone.0140801

Chłond D, Bugaj-Nawrocka A, Sawka-Gądek N. 2017. Are we witnessing speciation? A case study of the species Sirthenea flavipes (Stål, 1855) (Heteroptera: Reduviidae). Austral Entomology. https://doi.org/10.1111/aen.12320

Coscarón MC. 1983a. Nuevas citas distribucion geografica para la subfamilia Peiratinae (Insecta, Heteroptera, Reduviidae). Revista de la Sociedad Entomológica Argentina 42(1-4):368382

Coscarón MC. 1983b. Revision del genero Rasahus (Insecta, Heteroptera, Reduviidae). Revista del Museo de La Plata, (Nueva Serie) 13:75-138 
755 Coscarón MC. 1984. Sobre la presencia de especies de los generos Rasahus Amyot \& Serville, 756 Sirthenea Spinola y Tydides Stal para Peru (Heteroptera, Reduviidae, Peiratinae). Revista 757 de la Sociedad Entomológica Argentina 43(1-4):6

758 Coscarón MC. 1986. Revisión del género Eidmannia Taeuber, 1934 (Heteroptera, Reduviidae). 759 Revista Brasileira de Entomologia 30:303-305

760 Coscarón MC. 1994. Systematics and phulogenetic analysis of Thymbreus Stål (Heteroptera:

761 Reduviidae: Peiratinae). Zoologishe mededelingen, Leiden, 68(21):221-230

762 Coscarón MC. 1995. A new Neotropical genus of Peiratinae (Reduviidae, Heteroptera). Revista 763 Brasileira de Entomologia 39:453-457

764 Coscarón MC. 1996. Synonimizing Spilodermus Stål under Peirates Serville, and revision of the 765 766 767 768 769 resulting P.quadrinotatus species group (Heteroptera: Reduviidae: Peiratinae). Proceedings of the Entomological Society of Washington, 98(3):500-508

Coscarón MC. 1997a. Froeschnerisca nom. nov. for the junior homonym of Froeschneriellia Coscarón (Heteroptera: Reduviidae). Physis (Buenos Aires) 54:49

Coscarón MC. 1997b. Revision of the genus Peirates Serville, with a cladistics and biogeographic analysis (Heteroptera: Reduviidae, Peiratinae). Entomologica

772 Scandinavica 28:39-73

Coscarón MC. 2002. Systematic analysis of Calistocoris Reuter, 1881, Ceratopirates

773

774

775

776

777

778

779

780

781

782

783

784

785
Schouteden, 1933, and Pachysandalus Jeannel, 1916 (Heteroptera: Reduviidae: Peiratinae). Annales du Musée Royal de l'Afrique Centrale, Serie 8, Sciences Zoologiques 290:27-37

Coscarón MC. 2017. A catalogue of the Heteroptera (Hemiptera) or true bugs of Argentina. Zootaxa 4295(1):1-432 https://doi.org/10.11646/zootaxa.4295.1.1

Coscarón MC, Carpintero DL. 1994. Revision of the genus Melanolestes Stål (Heteroptera: reduviidae, Peiratinae). Entomologica Scandinavica 24:361-381

Coscarón MC, Morrone JJ. 1995. Systematic, cladistic, and biogeography of the Peirates collarti and P. lepturoides groups (Heteroptera: Reduviidae, Peiratinae). Entomologica Scandinavica 26(2):191-228

Coscarón MC, Linnavuori R. 2007. Redescription of Lestomerus (Brachysandalus) bicolor Villiers new synonymy of Peirates sin (Linnavuori) Coscarón (Heteroptera: Reduviidae. Peiratinae). Zootaxa 1439:65-68 
786 787

788

789

790

791

792

793

794

795

796

797

798

799

800

801

802

803

804

805

806

807

808

809

810

811

812

813

814

Coscarón MC, Morrone JJ. 1997. Cladistics and biogeography of the assassin bug genus Melanolestes Stål (Heteroptera: Reduviidae). Proceedings of the Entomological Society of Washington 99(1):55-59

Couvreur TLP, Forest F, Baker WJ. 2011. Origin and global diversification patterns of tropical rain forests: inferences from a complete genus-level phylogeny of palms. BMC Biology 9:44

Couvreur TLP, Baker WJ. 2013. Tropical rain forest evolution: palms as a model group. BMC Biology 11:48

Damgaard J. 2008) Phylogeny of the semiaquatic bugs (Hemiptera-Heteroptera, Gerromorpha). Insect Systematics \& Evolution, 39(4):431-460

Damgaard J, Andersen NM, Cheng L, Sperling FAH. 2000. Phylogeny of sea skaters, Halobates Eschscholtz (Hemiptera, Gerridae), based on mtDNA sequence and morphology. Zoological Journal of the Linnean Society 130:511-526

Davis CC, Webb CO, Wurdack KJ, Jaramillo CA, Donoghue MJ. 2005. Explosive radiation of malpighiales supports a mid-Cretaceous origin of modern tropical rain forests. American Naturalist 165:E36-E65

Fabricius JC. 1798. Supplementum entomologiae systematicae. Hafniae, Proft et Storch:572 pp.

Gil-Santana H, Costa LAA. 2003. Um novo gênero e espécie de Peiratinae de Nova Friburgo, Rio de Janeiro, Brasil (Hemiptera, Heteroptera, Reduviidae). Revista Brasileira de Zoologia 20(1):3-8

Goloboff PA, Catalano SA. 2016. TNT version 1.5, including a full implementation of phylogenetic morphometrics. Cladistics 32:221-238

Grimaidi D, Engel MS. 2005. Evolution of the Insects. Cambridge: Cambridge University Press:755 pp.

Horváth G. 1909. Species generis Reduviidarum Sirthenea Spinola. Annales Musei Nationalis Hungarici 7:356-369

Hwang WS, Weirauch C. 2012. Evolutionary history of assassin bugs (Insecta: Hemiptera: Reduviidae): insights from divergence dating and ancestral state reconstruction. PLoS ONE 7:e45523 
815 Jacobs BF. 2004. Palaeobotanical studies from tropical Africa: relevance to the evolution of 816 forest, woodland and savannah biomes. Philosophical Transactions of the Royal Society 817 B 359:1573-1583

818 Jaramillo C, Rueda MJ, Mora G. 2006. Cenozoic plant diversity in the neotropics. Science $819 \quad 311: 1893-1896$

820 Jaramillo C, Hoorn MC, Silva S, Leite F, Herrera F, Quiroz L, Dino R, Antonioli L. 2010. The 821 origin of the modern Amazon rainforest: implications from the palynological and paleobotanical record. In Amazonia, Landscape and Species Evolution. Edited by: Hoorn MC, Wesselingh FP. Oxford, UK: Blackwells:317-334

Johnson KR, Ellis B. 2002. A tropical rainforest in Colorado 1.4 million years after the

826

827 Cretaceous-Tertiary boundary. Science 296:2379-2383.

Jung S, Lee S. 2012. Correlated evolution and Bayesian divergence time estimates of the Cimicoidea (Heteroptera: Cimicomorpha) reveal the evolutionary history. Systematic Entomology 37:22-32 DOI: 10.1111/j.1365-3113.2011.00596.x

Katoh K, Misawa K, Kuma KI, Miyata T. 2002. MAFFT: a novel method for rapid multiple sequence alignment based on fast Fourier transform. Nucleic Acids Research 30(14):3059-3066

Lanfear R, Calcott B, Ho SY, Guindon S. 2012. PartitionFinder: combined selection of partitioning schemes and substitution models for phylogenetic analyses. Molecular Biology and Evolution 29:1695-1701

Lanfear R, Fransen PB, Wright AM, Senfeld T, Calcott B. 2016. PartitionFinder 2: new methods for selecting partitioned models of evolution for molecular and morphological phylogenetic analyses. Molecular Biology and Evolution 34:772-773

Li M, Tian Y, Zhao Y, Bu W. 2012. Higher level phylogeny and the first divergence time estimation of Heteroptera (Insecta: Hemiptera) based on multiple genes. PLOS ONE 7 (2):e32152

Livingstone D, Ambrose DP. 1984. Adaptative modifications of the Reduviidae of the scrub jungles and semi-arid zones of the Palghat Gap, India - an evolutionary approach. Journal of the Bombay Natural History Society 81(3):583-595

Maddison WP, Maddison DR. 2015. Mesquite: a modular system for evolutionary analysis. Version 3.5. http://www.mesquiteproject.org 
846 Maldonado Capriles J. 1990. Systematic Catalogue of the Reduviidae of the World (Insecta:

847 Heteroptera). Special edition of the Caribbean Journal of Science. University of Puerto

848 Rico, Mayagüez, PuertoRico:694 pp

849 McIntyre SRN, Lineweaver CH, Groves CP, Chopra A. 2017. Global biogeography since

$850 \quad$ Pangaea. Proceedings of the Royal Society of London B 284: 20170716

851 https://dx.doi.org/10.1098/rspb.2017.0716

852 Morley RJ. 2000. Origin and Evolution of Tropical Rain Forests New York, USA: John Wiley \& $853 \quad$ Sons:362 pp

854 Morrone JJ, Coscarón MC. 1996. Distributional patterns of the American Peiratinae

855 (Heteroptera: Reduviidae). Zoologishe mededelingen, Leiden 70(1):1-15

856 Morrone JJ, Coscarón MC. 1998. Cladistics and biogeography of the assassin bug genus Rasahus

857

858

859

860

861

862

863

864

865

866

867

868

869

870

871

872

873

874

875

Amyot \& Serville (Heteroptera: Reduviidae: Peiratinae). Zoologishe mededelingen, Leiden 72(6):73-87

Putshkov VG, Putshkov PV. 1986-1989. A Catalogue of the Reduviidae (Heteroptera) of the World. 6 Vols, Vinity, Lyubertsy:920 pp

Rambaut A, Drummond AJ. 2002-2018. TreeAnnotator. Ver.1.10.1. [Computer software and manual]. Available via http://beast.bio.ed.ac.uk/treeannotator.

Rambaut A, Suchard M, Xie D, Drummond A. 2014. Tracer v1.6 http://beast.bio.ed.ac.uk/Tracer.

Raven HP, Axelrod DI. 1974. Angiosperm biodiversity and past continental movements. Annals of the Missouri Botanical Garden 1(61):539-673.

Ronquist F, Teslenko M, Van Der Mark P, Ayres DL, Darling A, Höhna S, Larget B, Liu L, Suchard MA, Huelsenbeck JP. 2012. MrBayes 3.2: efficient Bayesian phylogenetic inference and model choice across a large model space. Systematic Biology 61:539-542

Sanger F, Nicklen S, Coulson AR. 1977. DNA sequencing with chain-terminating inhibitors. Proceedings of the National Academy of Sciences of the United States of America 74:5463-5467

Sanmartin I, Ronquist F. 2004. Southern Hemisphere Biogeography Inferred by Event-Based Models: Plant versus Animal Patterns. Systematic Biology 53(2):216-243 DOI: $10.1080 / 10635150490423430$ 
876 Schuh RT, Weirauch C, Wheeler WC. 2009. Phylogenetic relationships within the

877 Cimicomorpha (Hemiptera:Heteroptera): a total-evidence analysis. Systematic

$878 \quad$ Entomology 34(1):15-48

879 Simon C, Frati F, Beckenbach A, Crespi B. 1994. Evolution, weighting, and phylogenetic utility

880 of mitochondrial gene sequence and a compilation of conserved polymerase chain

881 reaction primers. Annals of the Entomological Society of America 87:651-701

882 Sklenarova K, Chesters D, Bocak L. 2013. Phylogeography of Poorly Dispersing Net-Winged

883

884

885

886

887

888

889

890

891

892

893

894

895

896

897

898

899

900

901

902

903

904

905 Beetles: A Role of Drifting India in the Origin of Afrotropical and Oriental Fauna. PLoS ONE 8(6):e67957. doi:10.1371/journal.pone.0067957

Song H, Buhay JE, Whiting MF, Crandall KA. 2008. Many species in one: DNA barcoding overestimates the number of species when nuclear mitochondrial pseudogenes are coamplified. Proceedings of the National Academy of Sciences of the United States of America 105:13486-13491

Suchard MA, Lemey P, Baele G, Ayres DL, Drummond AJ, Rambaut A. 2018. Bayesian phylogenetic and phylodynamic data integration using BEAST 1.10 Virus Evolution 4: vey016.

Tang W, Xu G, O’Brien CW, Calonje M, Franz NM, Johnston MA, Taylor A, Vovides AP, Pérez-Farrera MA, Salas-Morales SH, Lazcano-Lara JC, Skelley P, Lopez-Gallego C, Lindström A, Rich S. 2018. Molecular and Morphological Phylogenetic Analyses of New World Cycad Beetles: What They Reveal about Cycad Evolution in the NewWorld. Diversity 10(38):1-26. doi:10.3390/d10020038.

Upchurch GR, Wolf JA. 1987. Mid-Cretaceous to early tertiary vegetation and climate: evidence from fossil leaves and woods. In The Origin of Angiosperms and Their Biological Consequences. Edited by: Friis EM, Chaloner WG, Crane PR. Cambridge, UK: Cambridge University Press:75-105

Weirauch C. 2007. Hairy attachment structures in Reduviidae (Cimicomorpha, Heteroptera), with observations on the fossula spongiosa in some other Cimicomorpha. Zoologischer Anzeiger 246:155-175

Weirauch C. 2008. Cladistic analysis of Reduviidae (Heteroptera: Cimicomorpha) based on morphological characters. Systematic analysis of reduviidae (Heteroptera: 
906

907

908

909

910

911

912

913

914

915

916

917

918

919

920

921

922

923

924

925

926

927

928

929

930

931

932

933

934

935

936

Cimicomorpha) based on morphological characters. Systematic Entomology: https://doi.org/10.1111/j.1365-3113.2007.00417.x

Weirauch C, Berenger JM, Berniker L, Forero D, Forthman M, Frankenberg S, Freedman A, Gordon E, Hoey-Chamberlain R, Hwang WS, Marshall SA, Michael A, Paiero SM, Udah O, Watson C, Yeo M, Zhang G, Zhang J. 2014. An illustrated identification key to assassin bug subfamilies and tribes. Canadian Journal of Arthropod Identification 26:1115

Weirauch C, Munro JB. 2009. Molecular phylogeny of the assassin bugs (Hemiptera: Reduviidae), based on mitochondrial and nuclear ribosomal genes. Molecular Phylogenetics and Evolution 53(1):287-299

Wieczorek K, Lachowska-Cierlik D, Kajtoch $€$, Kanturski M. 2017. The relationships within the Chaitophorinae and Drepanosiphinae (Hemiptera, Aphididae) inferred from molecularbased phylogeny and comprehensive morphological data. PLOS ONE 12 (3):e0173608. https://doi.org/10.1371/journal.pone.0173608

Wing SL, Herrera F, Jaramillo CA, Gómez-Navarro C, Wilf P, Labandeira CC. 2009. Late Paleocene fossils from the Cerrejón formation, Colombia, are the earliest record of neotropical rainforest. Proceedings of the National Academy of Sciences of the United States of America 106:18627-18632

Ye Z, Damgaard J, Burckhardt D, Gibbs G, Yuan J, Yang H, Bu W. 2018. Phylogeny and historical biogeography of Gondwanan moss-bugs (Insecta: Hemiptera: Coleorrhyncha: Peloridiidae). Cladistics 0:1-15 DOI: 10.1111/cla.12237

Zhang J, Weirauch C, Zhang G, Forero D. 2016a. Molecular phylogeny of Harpactorinae and Bactrodinae uncovers complex evolution of sticky trap predation in assassin bugs (Heteroptera: Reduviidae). Cladistics 32:538-554

Zhang J, Gordon ERL, Forthman M, Hwang WS, Walden K, Swanson DR, Johnson KP, Meier R, Weirauch C. 2016b. Evolution of the assassin's arms: insights from a phylogeny of combined transcriptomic and ribosomal DNA data (Heteroptera: Reduvioidea). Scientific Reports 6:22177 doi: 10.1038/srep22177.

\section{Acknowledgments}


937

938

The first author would like to thank to Wanzhi Cai (CAU), Dávid Rédei (HNHM), Diego

939 José Carpintero (MACN), Maria Cecilia Melo (MLPA), Petr Baňař (MMBC), Eric Guilbert

940 (MNHN), Anders Albrecht (MZH), Daniel Burckhardt (NHMB), Henrik Enghoff (NHMD),

941 Mick Webb (NHMUK), Herbert Zettel (NHMW), Gunvi Lindberg (NHRS), Petr Kment

942 (NMPC), Jerome Constant (RBINS), Eliane de Coninck (RMCA), Yvonne van Nierop (RMNH),

943 Stephan Blank (SMF), Ernst Heiss (TLMF), Roland Dobosz (USMB), Thomas J. Henry

944 (USNM), Zdeněk Jindra (ZJPC), Yvonne van Nierop (RMNH) and Jürgen Deckert (ZMHB) for

945 the possibility of studying the material in the collections under their curation. We are grateful to

946 the CIPRES Scientific Gateway that provides access to computational resources.

947 Figure legends

948

949 Figure 1. Morphological characters: a - Sirthenea nigronitens (Miller, 1958), head and thorax; b 950 - Calistocoris virgo Reuter, 1881, head; c - S. picescens Reuter, 1887, head; d - S. amazona Stål, 951 1866, head; e - S. amazona Stål, 1866, pronotum; f - Androclus granulatus Stål, 1863, head; g 952 S. picescens Reuter, 1887, pronotum; h-S. laevicollis Horváth, 1909, head; i - S. caiana 953 Chłond, 2008, head and pronotum; j-Platymeris rhadamanthus Gerstaecker, 1873, head and 954 thorax.

955 Figure 2. Morphological characters: a - Platymeris rhadamanthus Gerstaecker, 1873, head and 956 thorax; b - Sirthenea peruviana Drake \& Harris, 1945, thorax; c - S. laevicollis Horváth, 1909,

957 fossula spongiosa on middle tibia; d - S. laevicollis Horváth, 1909, structure of fossula 958 spongiosa; e - S. flaviceps (Signoret, 1860), fossula spongiosa on fore tibia; $\mathrm{f}$ - Ectomocoris 959 ululans (Rossi, 1807), fossula spongiosa on fore tibia; g - E. ululans (Rossi, 1807), head; h-E. 960 ululans (Rossi, 1807), hemelytron; i - S. flaviceps (Signoret, 1860), hemelytron; j - S. ferdinandi 961 Willemse, 1985, scutellum; k - S. flavipes (Stål, 1855), scutellum; 1 - S. pedestris Horváth, 1909, 962 hemelytron; $\mathrm{m}$ - S. flavipes (Stål, 1855), abdomen; $\mathrm{n}-$ S. laevicollis Horváth, 1909, abdomen; o $963-$ S. nitida Chłond, 2008, abdomen. 
964 Figure 3. Morphological characters: a - S. pedestris Horváth, 1909, male pygophore; b -

965 Peirates strepitans Rambur, 1839, additional process on VII abdominal sternite of male and

966 pygophore; c - S. dimidiata Horváth, 1911, reduced hemelytron; d - S. dimidiata Horváth, 1911,

967 right paramere; e $-S$. dimidiata Horváth, 1911, left paramere; f - S. setosa Chłond, 2018, right

968 paramere; $\mathrm{g}$ - S. setosa Chłond, 2018, left paramere; h - Platymeris rhadamanthus Gerstaecker,

969 1873, right paramere; i - Platymeris rhadamanthus Gerstaecker, 1873, left paramere; j - S.

970 dimidiata Horváth, 1911, median process of pygophore; $\mathrm{k}-\mathrm{S}$. setosa Chłond, 2018, median

971 process of pygophore; 1 - S. nigra Cai \& Tomokuni, 2004, median process of pygophore.

972 Figure 4. Estimated ages of divergence for the Sirthenea genus created using BEAST. Branch

973 lengths are drawn proportional to time. 95\% highest posterior density intervals for nodes are

974 indicated by horizontal blue bars. Taxa are highlighted by their biogeographical occurrence

975 (yellow - Asia, blue - Madagascar, black - Africa, green - Australia, red - Americas).

976 Figure 5. Fifty per cent majority rule consensus tree from a Bayesian analysis of

977 morphological dataset. Posterior probabilities are shown at the respective nodes.

978 Figure 6. Fifty per cent majority rule consensus tree from a partitioned Bayesian analysis of 979 molecular dataset. Posterior probabilities are shown at the respective nodes.

980 Figure 7. Fifty per cent majority rule consensus tree from a partitioned Bayesian analysis of a 981 combined data set (DNA and morphology). Posterior probabilities and jackknife values are 982 shown at the respective nodes separated by a forward slash '/. If a node was unsupported by the $983 \mathrm{BI}$ or MP analysis a hyphen '-' is given.

984 Supplementary Information.

985 S1. Detailed list of specimens examined for the morphological data matrix with information 986 about localities of collection (DOCX).

987 TableS1. Detailed information of specimens and GenBank accession numbers for the sequenced 988 data (DOCX).

989 TableS2. Morphological data matrix (csv). 


\section{Figure 1}

Morphological characters

a - Sirthenea nigronitens (Miller, 1958), head and thorax; b-Calistocoris virgo Reuter, 1881, head; c - S. picescens Reuter, 1887 , head; d - S. amazona Stål, 1866, head; e - S. amazona Stål, 1866, pronotum; f - Androclus granulatus Stål, 1863, head; g - S. picescens Reuter, 1887 , pronotum; h - S. laevicollis Horváth, 1909, head; i - S. caiana Chłond, 2008, head and pronotum; j - Platymeris rhadamanthus Gerstaecker, 1873, head and thorax. 


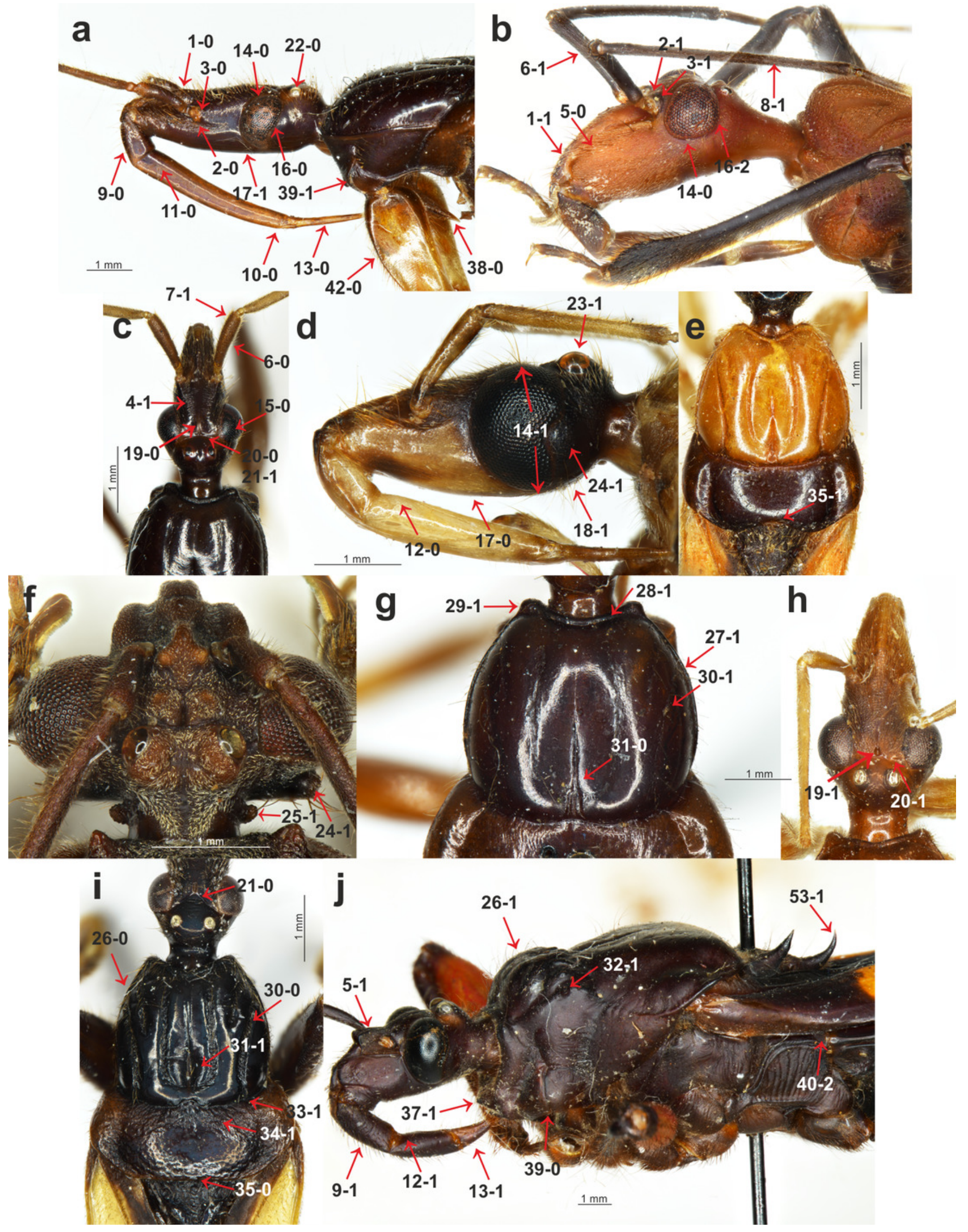




\section{Figure 2}

Morphological characters

a - Platymeris rhadamanthus Gerstaecker, 1873, head and thorax; $b$ - Sirthenea peruviana Drake \& Harris, 1945, thorax; c - S. laevicollis Horváth, 1909, fossula spongiosa on middle tibia; d - S. laevicollis Horváth, 1909, structure of fossula spongiosa ; e - S. flaviceps (Signoret, 1860), fossula spongiosa on fore tibia; $\mathrm{f}$ - Ectomocoris ululans (Rossi, 1807), fossula spongiosa on fore tibia; g - E. ululans (Rossi, 1807), head; h - E. ululans (Rossi, 1807), hemelytron; i - S. flaviceps (Signoret, 1860), hemelytron; j - S. ferdinandi Willemse, 1985, scutellum; k - S. flavipes ( Stål, 1855), scutellum; I - S. pedestris Horváth, 1909, hemelytron; m - S. flavipes ( Stål, 1855), abdomen; n - S. laevicollis Horváth, 1909, abdomen; 0 - S. nitida Chłond, 2008, abdomen. 

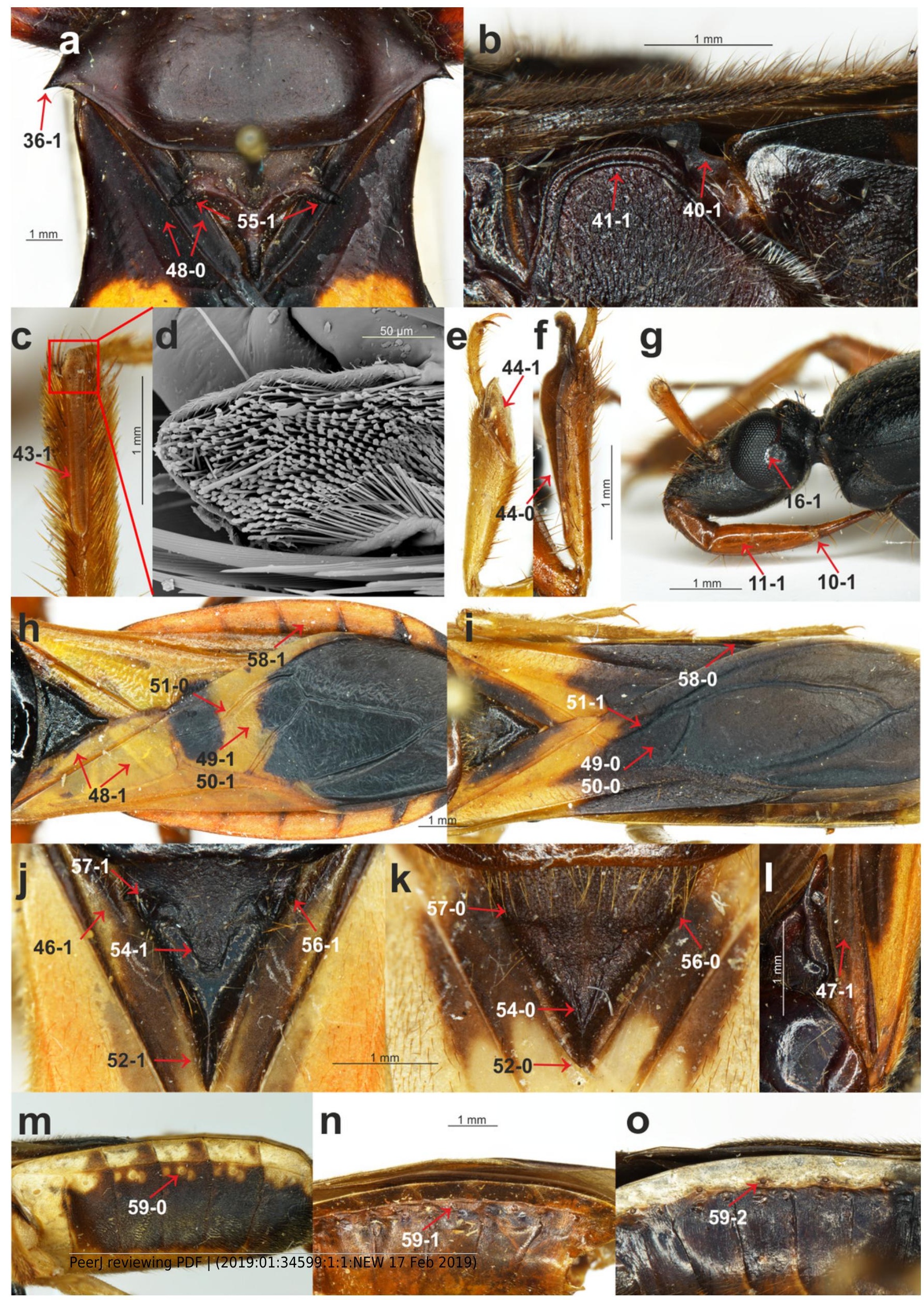


\section{Figure 3}

Morphological characters

a - S. pedestris Horváth, 1909, male pygophore; b - Peirates strepitans Rambur, 1839, additional process on VII abdominal sternite of male and pygophore; c - S. dimidiata Horváth, 1911, reduced hemelytron; d - S. dimidiata Horváth, 1911, right paramere; e - S. dimidiata Horváth, 1911, left paramere; $\mathrm{f}$ - S. setosa Chłond, 2018, right paramere; g - S. setosa Chłond, 2018, left paramere; h - Platymeris rhadamanthus Gerstaecker, 1873, right paramere; i - Platymeris rhadamanthus Gerstaecker, 1873, left paramere; j - S. dimidiata Horváth, 1911, median process of pygophore; k - S. setosa Chłond, 2018, median process of pygophore; I - S. nigra Cai \& Tomokuni, 2004, median process of pygophore.

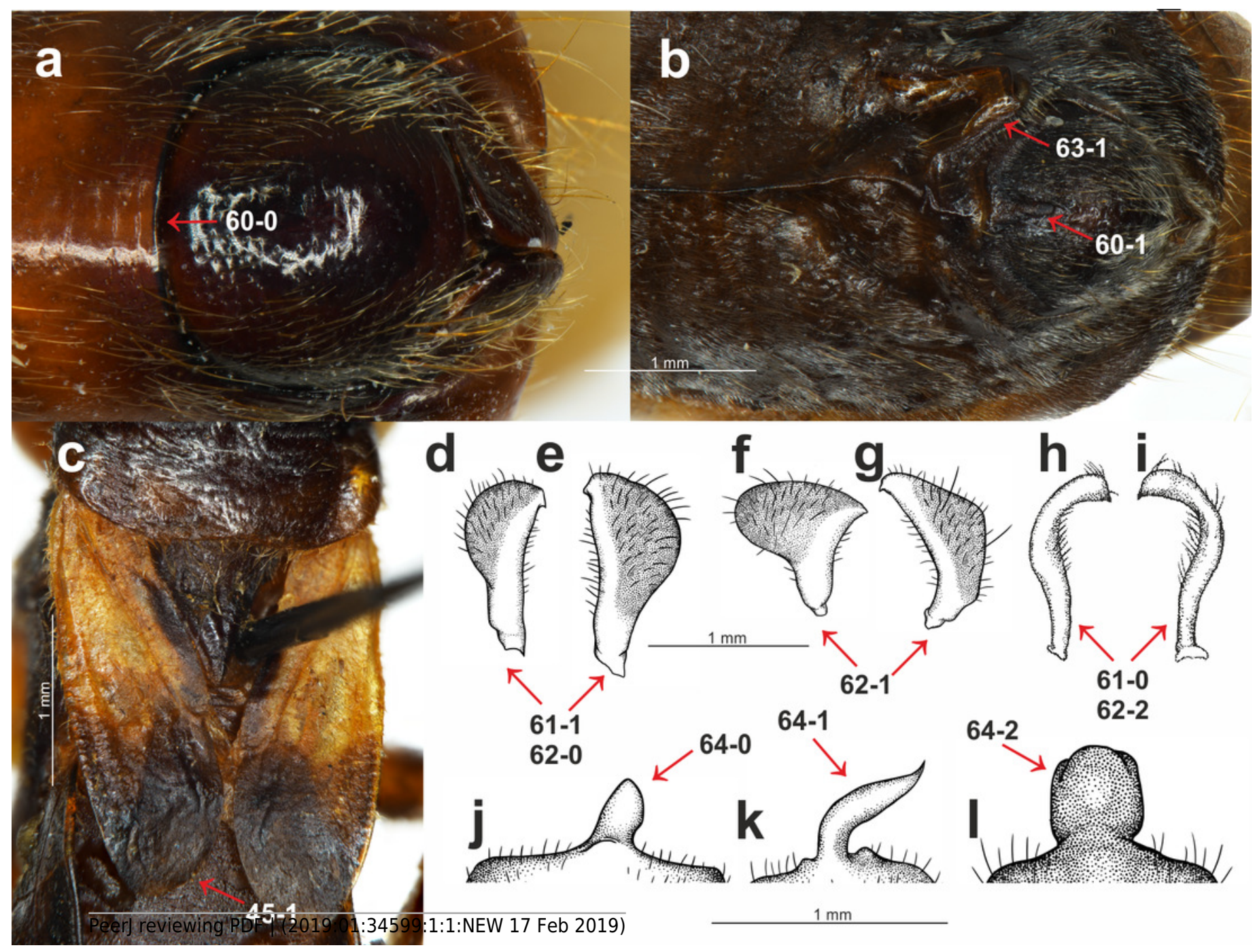


Figure 4 (on next page)

Estimated ages of divergencefor the Sirthenea genus created usingBEAST. Branch lengths are drawn proportional to time. 95\% highest posteriordensity intervals for nodes are indicated by horizontal blue bars. Taxa arehighlighted by their biogeograph 


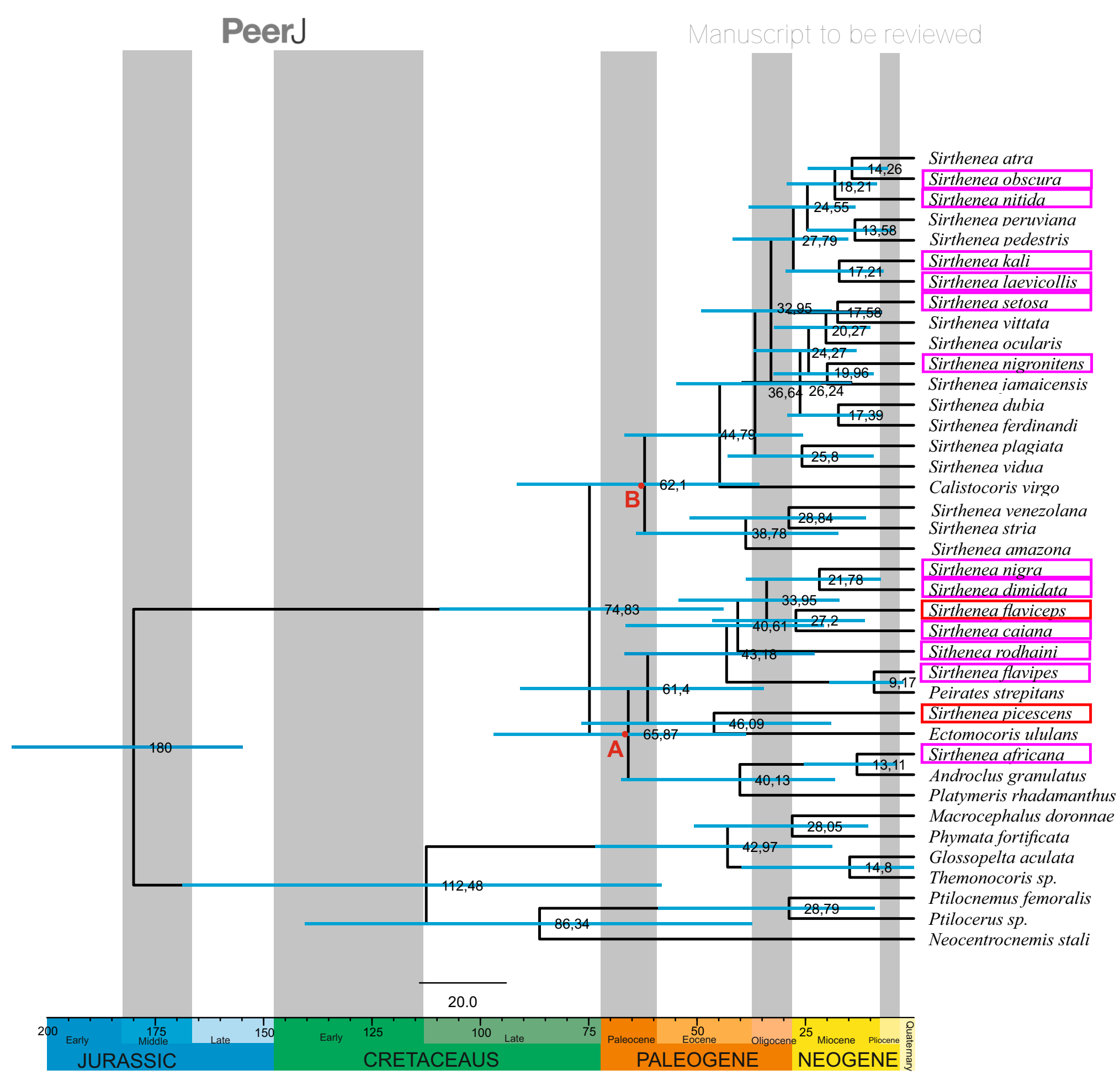




\section{Figure $\mathbf{5}$ (on next page)}

Fifty per cent majority ruleconsensus tree from a Bayesian analysis of morphological dataset. Posteriorprobabilities are shown at the respective nodes. 
Androclus granulatus

\section{Ectomocoris ululans}

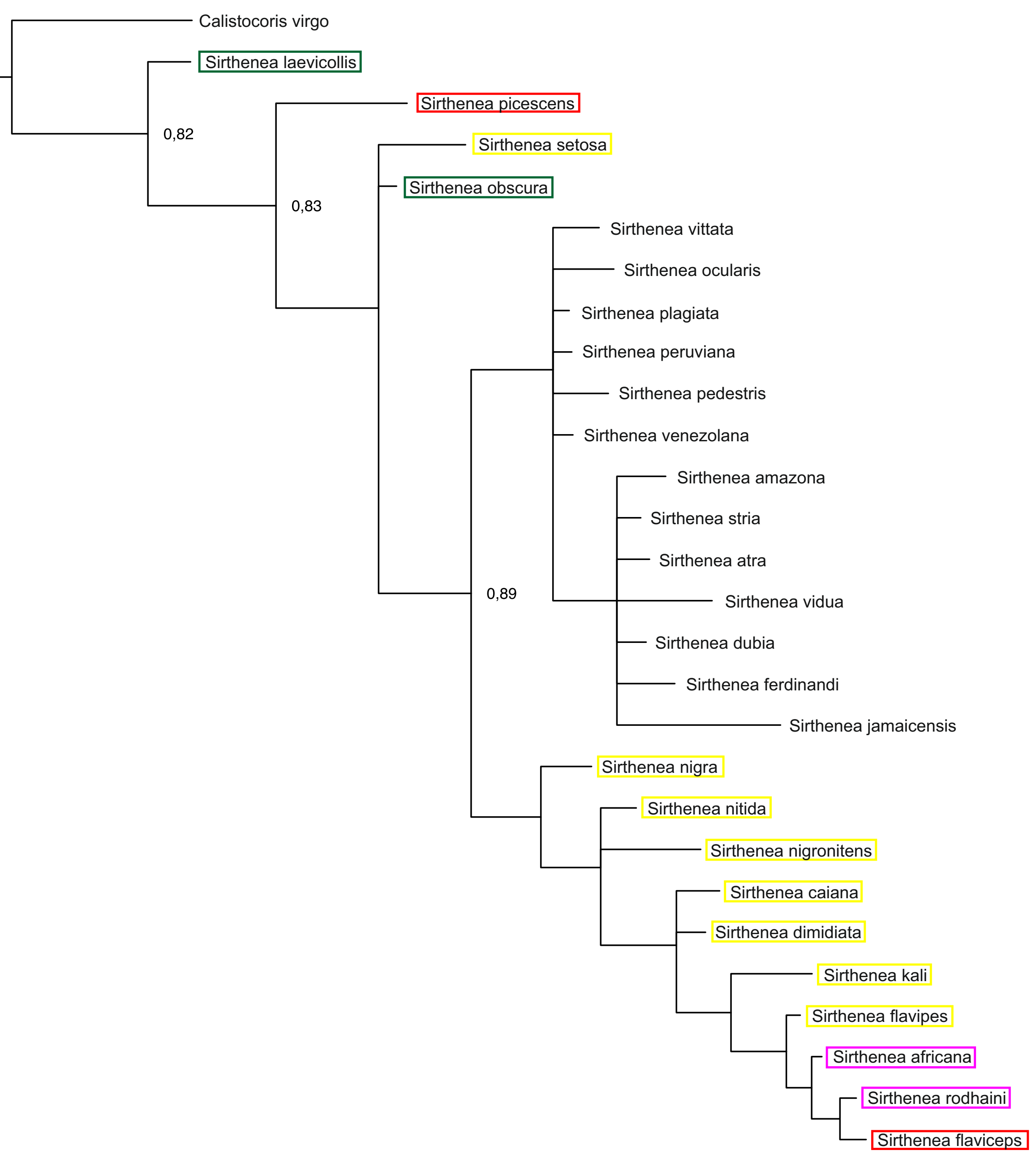




\section{Figure 6 (on next page)}

Fifty per cent majority ruleconsensus tree from a partitioned Bayesian analysis of molecular dataset.Posterior probabilities are shown at the respective nodes. 


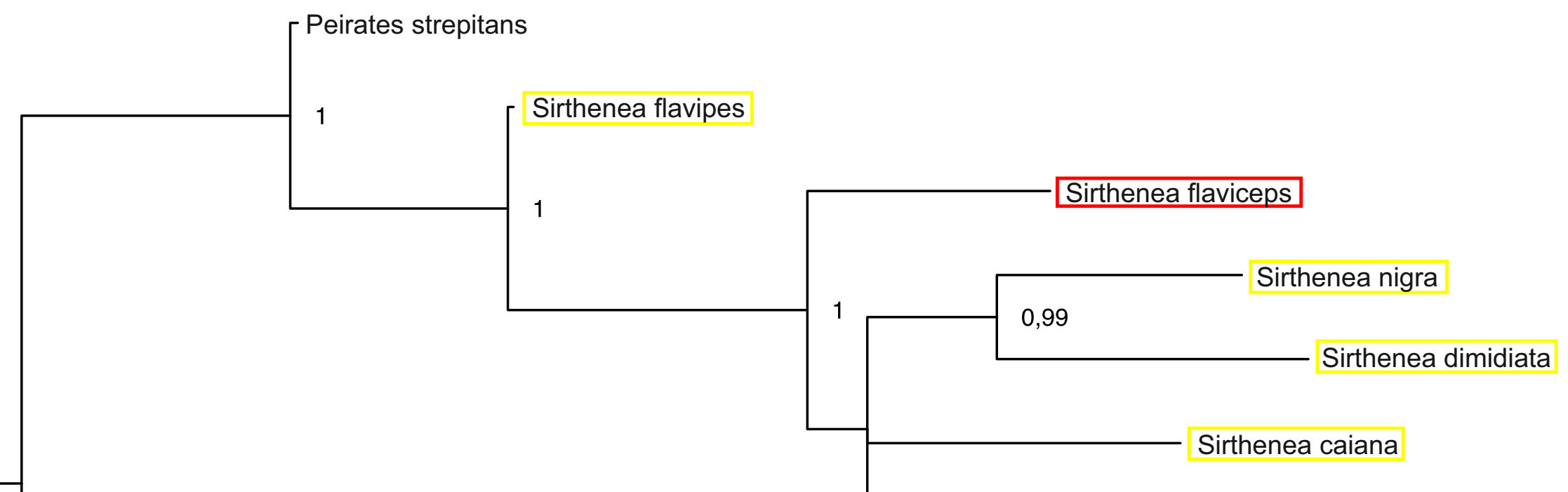

Sirthenea rodhaini

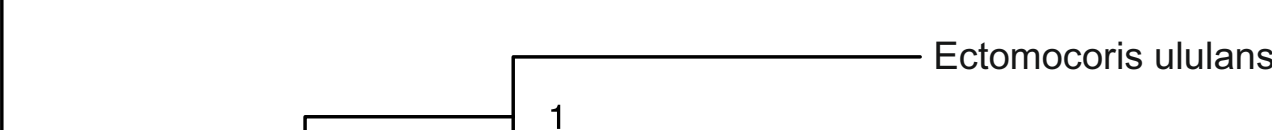

1

Sirthenea picescens
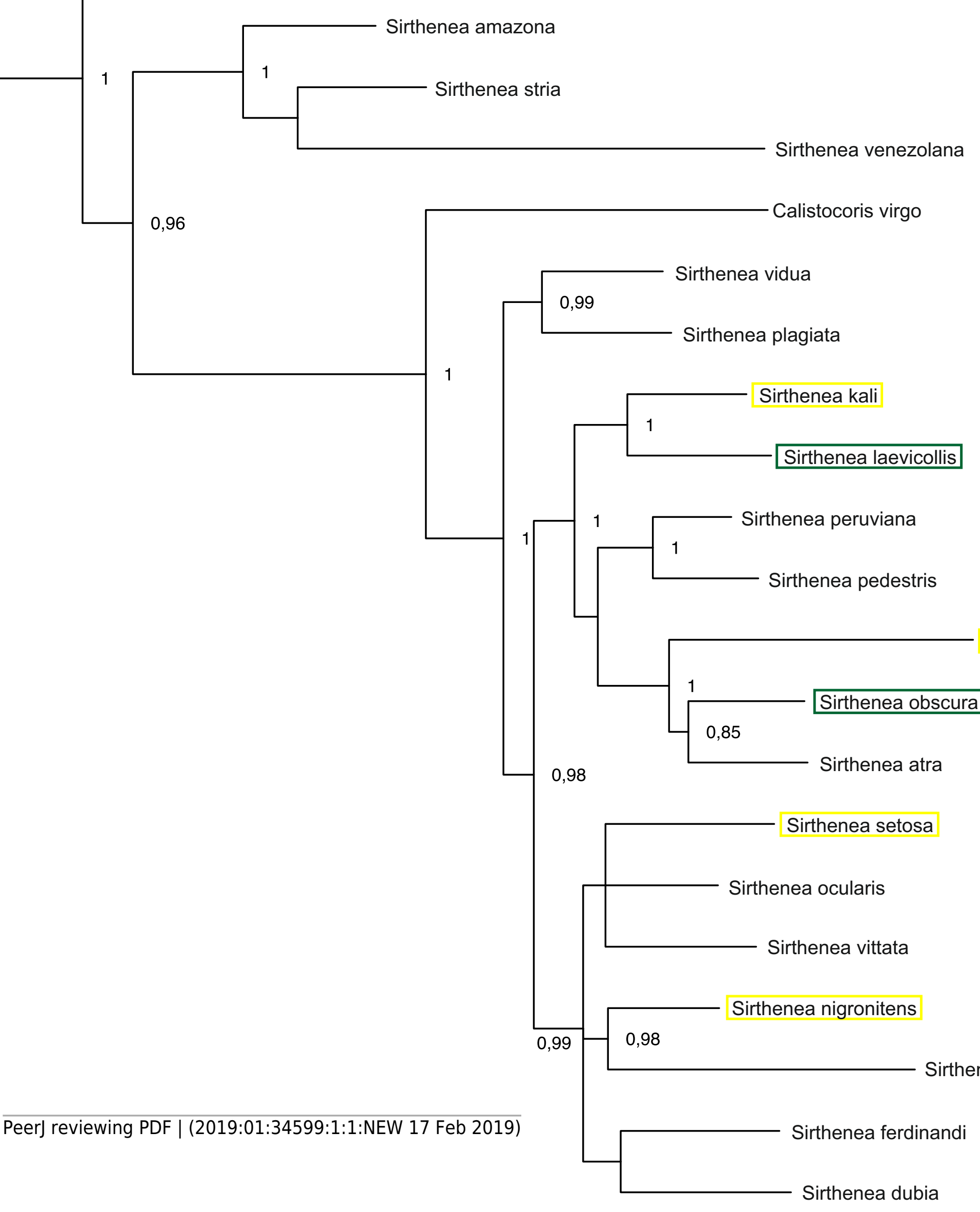


\section{Figure 7 (on next page)}

Fifty per cent majority rule consensus tree froma partitioned Bayesian analysis of a combined data set (DNA and morphology).Posterior probabilities and jackknife values are shown at the respective nodesseparated by a forward slash ' $\%$ '. If a node was unsup 
Pelaricana

Peirates strepitans

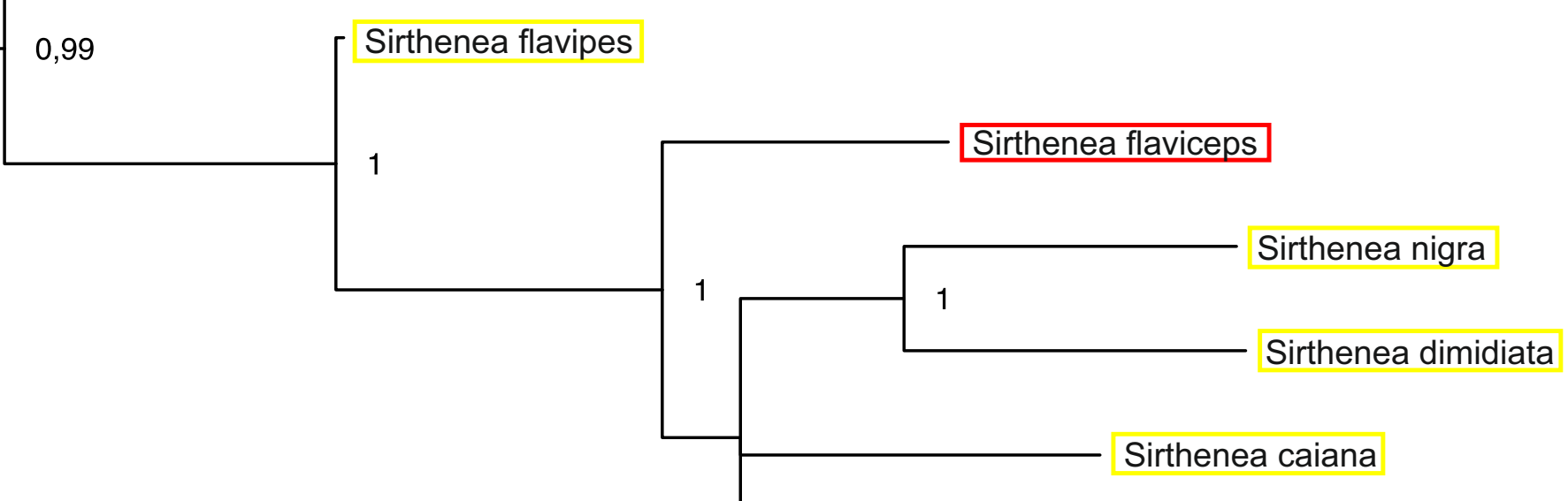

Sirthenea rodhaini

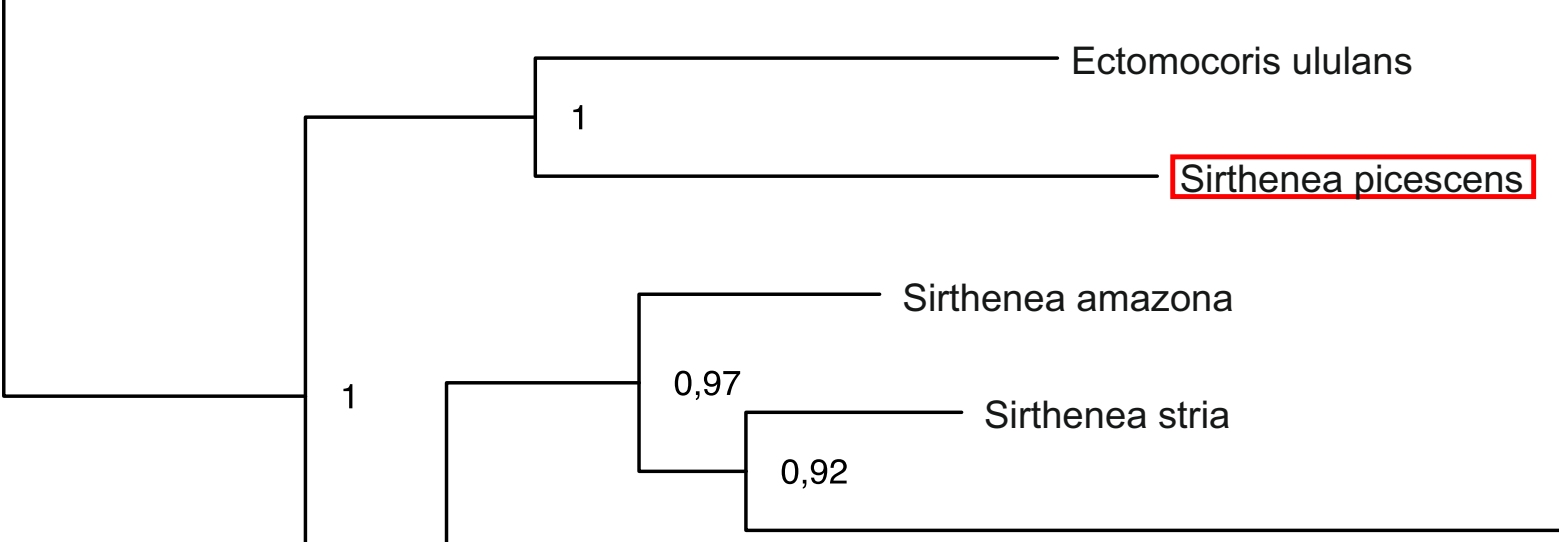

Sirthenea venezolana

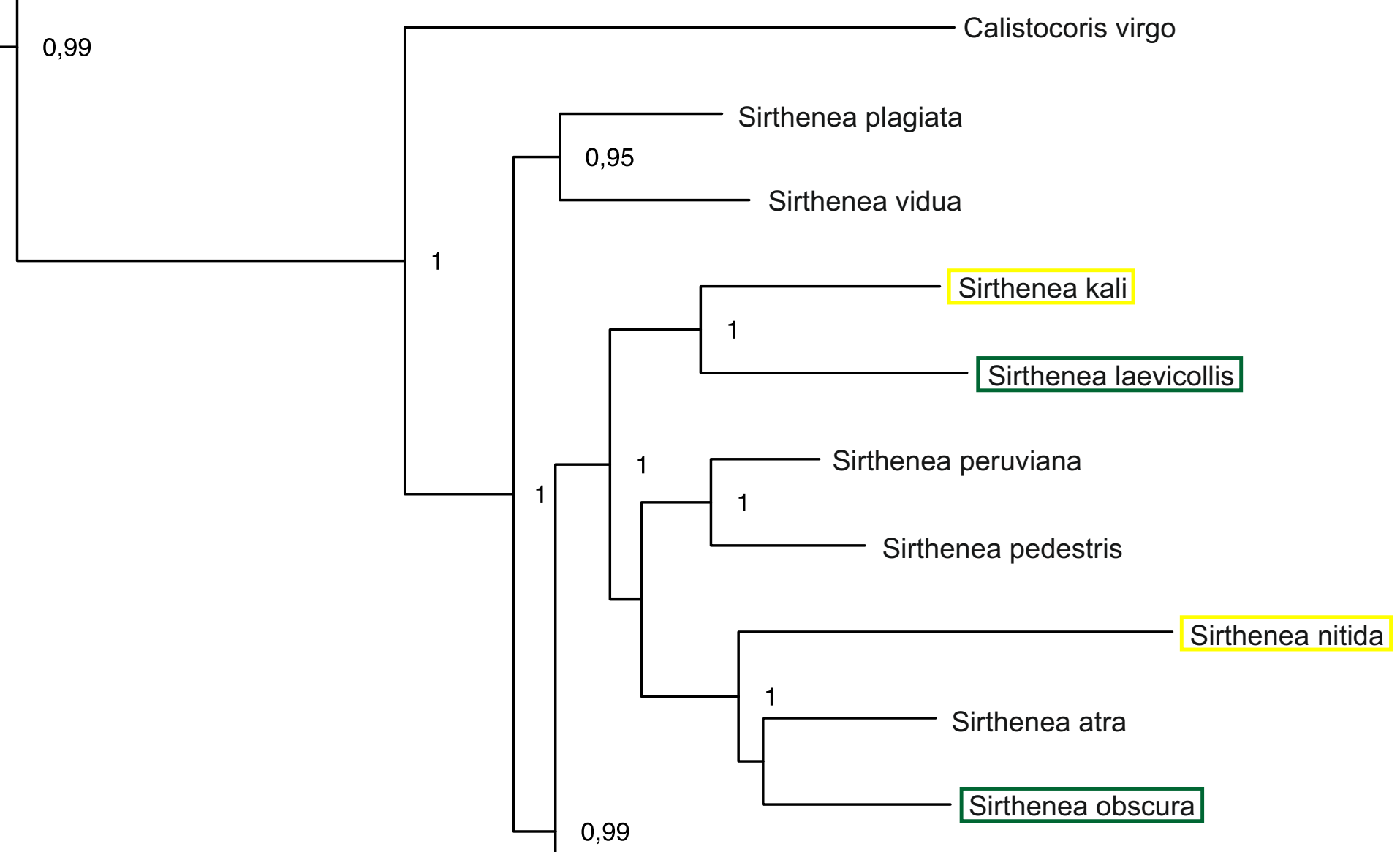

Sirthenea vittata

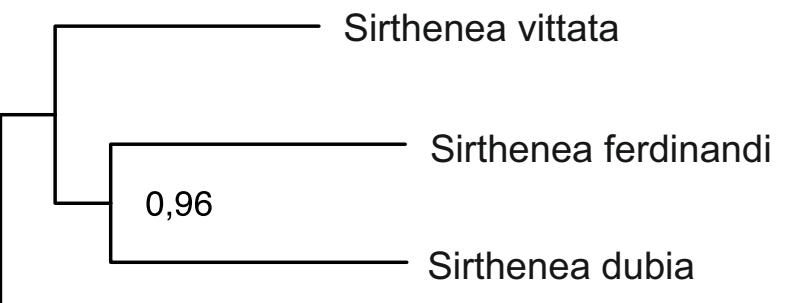

Sirthenea ocularis

Sirthenea nigronitens

0,99 